\title{
BAD COMPANY: The CORPORATE APPROPRiation OF Nature, Divinity, and Personhood in U.S. Culture
}

\author{
Richard Hardack*
}

\begin{abstract}
In this article, I provide a cultural history of some of the critical predicates of corporate personhood. I track the Hobbesian lineage of the corporate form, but also the ways the corporation, ascribed with numinous agency and personhood, has filled the cultural space vacated by our transcendence of anthropomorphic notions of god and Nature.

The corporation was created through the consent of the sovereign, and its charter was formulated to reflect not only its uses, but its potential threat, particularly with regard to its concentration of power. Established under the aegis of individual states, the U.S. corporation was initially restricted to specific functions for limited periods. But corporations in many contexts not only have supplanted the Hobbesian state that created them, but displaced the individual person.

Corporations have become super-persons and forms of sovereigns themselves, in part by acquiring human rights and "personalities" and tethering them to the corporation's inhuman attributes. However, corporations don't just mimic human behaviors; at best simulacra, or imitations of human life, corporations challenge and destabilize the status of personhood, and what it means to be a person.

In the process, corporations have amassed not just wealth, but personhood (for example, in perhaps surprising ways, the personhood of African Americans). In many ways, the ever-increasing wealth gap in the United States is actually a personhood gap. The overarching effect of corporate personhood, which operates in tandem with privatization, is to dehumanize people, turning them into things that have no rights. Created to encourage entrepreneurial (or reckless and socially irresponsible) risktaking and minimize personal liability, the corporation evolved into an entity that dynamically diminishes the personal.

The corporation represents a collective, transcendental body that has taken on the role of a deity, and, in U.S. ontology, of nature. The relationships between human and corporate personhood and identity implicate fantasies of the supernal; the superhuman; immortality; and the transcendence of individuality. For these reasons, I treat the corporation not primarily as a commercial enterprise, but as a cultural phantasm, a kind of black hole that draws in more and more cultural phenomena
\end{abstract}

* Richard Hardack received his doctorate in English and J.D. from UC Berkeley, and has taught English and American Studies, Law, and Public Health Law at UC Berkeley, and Haverford and Bryn Mawr Colleges. He has published more than forty articles in American Studies and Literature and Law, and was recently lead author of a white paper written for the U.C. Berkeley Center for Law, Business \& the Economy. His first book, "Not Altogether Human": Pantheism and the Dark Nature of the American Renaissance, was published in 2012 by the University of Massachusetts Press, and he is currently completing two books, Coming Between Africa and America: Transcendentalism and the Transcendence of Race, from Emerson to Morrison, and New and Improved: The Zero-Sum Game of Corporate Personhood. He is also project editor for NASA's official history of the Juno mission to Jupiter. 
into its orbit. The modern corporation has come to guarantee certain rights at a price, in much the way the Hobbesian state once did. People barter their attributes to corporations; but they are no longer trading liberty for security, but "souls" for identity. As the corporation comes to serve as the de facto guarantor and distributor of culture, it remains amoral at best, and in practice serves as a dominant pathological personality that helps reduce all human endeavor to commercial interest.

\section{KEYWORDS}

Corporate Personhood, Thomas Hobbes, Critical Legal Theory, Race, Citizens United case

\section{CONTENTS}

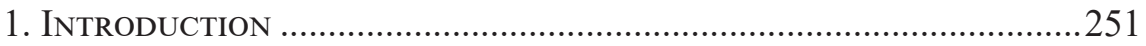

II. INCORPORATING NATURE..........................................................25

III. Corporate Mergers and Corporate Animation .........................2258

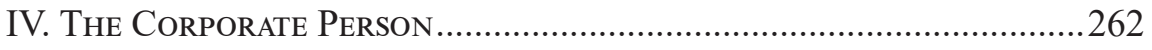

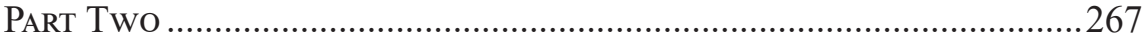

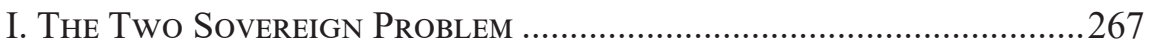

II. The Artificial Person ..................................................................... 270

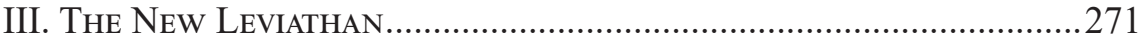

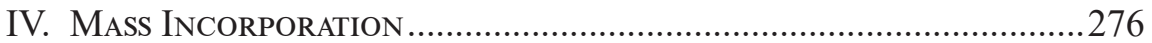

V. BeHIND THE VeIL ........................................................................281

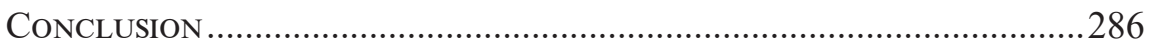

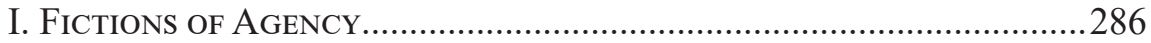




\section{INTRODUCTION}

In the manner of subliminal advertising, the corporate communications that warn you that someone might be stealing your identity also might be acknowledging that corporations are responsible for the biggest identity theft in history. If corporations are now alive, and have become persons, human beings might already be dead things. In this article, I provide a condensed, necessarily elliptical cultural history of some of the critical concepts pertaining to the impersonal impersonations that constitute corporate personhood. By examining the naturalization, animation, legal authorization and structural deification of the corporate person, I hope to illuminate the ways corporations walk, disembodied, among us.

In a prior publication, I coined the term corpography to connote the limited forms of self-representation-such as advertisements, filings, and corporate histories - that corporations can generate. ${ }^{1}$ Advertising, the corporate speech I described as impersonal and depersonalizing, provides a primary means for creating corporate identities, which I define as only a network of representations that reify corporations as coherent, continuous and personalized entities. That discourse inures us to the fantasy that we can relate to corporations as organizations with intrinsic human(oid) characteristics, rather than as legal fabrications or bureaucratic machines. Though it is highly mediated, advertising is the closest thing to an autobiographical utterance a corporation can make. Most external biographical representations of a "corporation" internalize the fantasy that the corporate structure can be incarnated, and narrativize and dramatize the corporate brand as if it were in key registers personable, or impersonable.

I also argued that personhood is a zero sum game, and that the more "personhood" and human rights a corporation attains, the less of those traits and rights people retain. Because it is a purely metaphorical contrivance, the concept of corporate personhood is often represented through images of mechanical, generic, and vampyric forms of existence. In other words, impersonal corporate systems mimic human processes and interactions, or uncannily but defectively imitate and siphon the personal qualities of people - they are entities that steal identities. I focus here not on advertising, but the causes and effects of corporate ontology in the U.S. in cultural and legal terms.

I track the Hobbesian lineage of the corporate form, but also the ways the corporation has filled the cultural space vacated by our abnegation of anthropomorphic notions of god and Nature (i.e., other personified fictions of collective existence that preceded it. I capitalize Nature at points to connote a deified, impersonally personified, and transcendental entity). I briefly touch on the disturbing ways in which pantheist and neo-vitalist theories of Gaea, which personify Nature as a living Being with a soul and agency, can reflect corporate ontologies and help substantiate the legal and deontological frameworks that afford corporations souls and personhood. The pressing question is whether corporations conceptually are persons or nightmarish things impersonating persons.

See Richard Hardack, New and Improved: The Zero-Sum Game of Corporate Personhood, 37 BIOGRAPHY: INTERDISC. Q. 36 (2014) (a special issue on life-writing and corporate personhood). All emphases in this article are added unless noted as "eio" (emphasis in original). 
Commercial entities with strictly delimited rights and liabilities, corporations are created at the largesse of governments or sovereigns; as such, they are ineluctably artificial and contingent. In the well-known U.S. Supreme Court case of Dartmouth College v. Woodward, Chief Justice John Marshall asserted that "Being the mere creature of law, [the corporation] possesses only those properties which the charter of its creation confers upon it, either expressly or as incidental to its very existence." ${ }^{2}$ Established by public charter and under the aegis of individual states, the U.S. corporation was initially restricted to specific functions, and often for limited periods and with caps on its accumulation of capital. The corporation existed through the consent of the sovereign, and was formulated to reflect not only its uses, but its hazards, particularly with regard to its concentration of power. Herbert Hovenkamp reminds us of a stricture that courts often forget, that "the corporation has only those powers granted to it by the sovereign."” But, as I argue throughout, corporations have become forms of sovereigns themselves, primarily by acquiring human rights and "personalities" and tethering those qualities to the corporation's inhuman attributes. Though now credited with personhood, corporations cannot act with univocal intention or possess agency. They are at best simulacra, imitations of human life. But corporations don't just mimic human behaviors; they chronically challenge and destabilize the status of personhood, and what it means to be a person.

The only interest a corporation has under its charter is commercial-it is created for a strictly mercantile purpose. ${ }^{4}$ No autonomous person exists in the formal corporate domain to generate views, or voice speech, other than agents who make commercial representations regarding the corporation on its behalf. Many other groups and associations can voice any kind of speech-they are not bound by charters, and their privileges were not designed to be balanced by equivalent restrictions. No doubt, such entities face their own problems in voicing the views of a collective, but they are at least in critical ways disconnected from the directives and constraints of the for-profit corporation. Unlike NGOs, partnerships and most other organizations, the large corporation a priori creates a nearly absolute separation between not only owners and actors and agents, but between the empty, unpeopled structure of the corporation and the dehumanized people who serve it. It is worth noting that no partnerships ever have claimed a soul, and far fewer of them than corporations ever have threatened eco-systems, national financial systems, or the health of their customers.

In many ways, the ever-increasing wealth gap in the United States is actually a personhood gap. The effect of corporate personhood, which operates in tandem with privatization, is to dehumanize people, turning them into things that have no

\footnotetext{
Trustees of Dartmouth Coll. v. Woodward, 17 U.S. (4 Wheat.) 518, 636 (1819).

Herbert Hovenkamp, The Classical Corporation in American Legal Thought, 76 Geo. L.J. 1593, 1645 (1988).

4 Non-profit corporations - for example, most universities - are distinct entities, but even they increasingly are infiltrated by the structures, expectations, and behaviors of for-profit corporations. Even most B corporations, the relatively miniscule number of corporations that are dedicated to social causes such as renewable energy, are still defined and constrained by the corporate form; while some of these businesses behave much more responsibly than the average corporation, they still use their social agendas to promote their businesses, and to brand themselves as putatively anti-corporate, while still taking advantage of the corporate form.
} 
rights - not the right to have access to healthcare, education, or courts rather than arbitration; to retire; to unionize; to speak; and even to vote. Many of those rights have been directly and indirectly transferred to corporations that can lobby and set agendas ranging from taxation to healthcare, education, military spending, election rules, gerrymandering and campaign spending. As codified by the ironically titled Citizens United case, infra - the 2010 Supreme Court case that held that corporate money is speech and affirmed that corporations are people-corporations have come to control speech and representation in almost all media. It therefore becomes critical to track the manifold cultural, aesthetic, legal, and ontological inversions that have allowed corporations to regulate the state. The causes and effects of these inversions affect society at all levels and in all contexts. As one disturbing example, it is now commonplace for many corporations, even those not immediately involved in information technology or social media, to refer to persons as the products rather than the consumers. Virtually all media, which now includes everything from entertainment to politics, serve as a pretext or lure for corporate advertising and manipulation, and a distraction from corporate maneuvering. All these inversions and effects are intimately predicated on the notion that the corporation is now the person.

\section{INCORPORATING NATURE}

To address the evolving and troubling relationship of the corporation to personhood in U.S. culture, one needs to consider its affiliations with, and divergences from, Nature and the nation-state. I argue that a once deified Nature, which was also putatively animated with some form of a soul, has been superseded directly by the Corporation with a soul, which begins to take on the exceptional, numinous, or inhuman characteristics of the divine-it is a disembodied, collective thing that is animated, ubiquitous and theoretically immortal. The corporation also is engaged in a zero-sum game with Nature, and finally the nation-state. According to Marx, "The devaluation of the human world increases in direct relation with the increase in value of the world of things." $"$ Today, that world is represented by the corporation, the quintessential uncanny Thing whose "human" status, rights and qualities grow as, and only when, those of people are diminished. In tracing how the corporation comes to take on and over the attributes of Nature beginning around the time of the Civil War, one encounters a consistent rhetoric of merger, animation, impersonation, impersonality, artificial life or intelligence, and a transcendence of individual human identity common to both entities.

The relationship between human and corporate personhood and identity implicates our interactions with religion, deified Nature and sacrificial systems of gift exchange. For these reasons, I treat the corporation not primarily as a commercial enterprise - though its legal and economic functions are of course vital to its existence - but as a cultural phantasm, a kind of black hole that draws in more and more cultural phenomena into its orbit. In a variety of contexts, people barter their attributes to corporations - they are not trading liberty for security, but "souls"

5 Karl Marx, The Economic and Philosophical Manuscripts: Early Writings 32324 (Rodney Livingstone \& Gregor Benton trans., 1975). 
for identity. As I will argue, the contemporary corporation has come to guarantee certain rights at a price, in much the way the Hobbesian state once did. As the corporation comes to serve as the de facto guarantor and distributor of culture, it can be amoral at best, and in practice it serves as a dominant pathological personality and helps reduce all human endeavor to commercial interest. Almost everything produced in that culture will reflect that pathology and priority. Ironically, the expansion of corporate rights has periodically proceeded under the unwittingly masochistic claims of corporate owners, as in Burwell v. Hobby Lobby Stores, Inc.; it is as if hosts were agitating for the privileges and prerogatives of parasites. ${ }^{6}$ Perversely, unaware they are participating in a zero-sum game, plaintiffs in these cases seek to transfer aspects of their own personhood and personal rights legally to the corporate form; it is quite the devil's bargain to attain "religious freedom" for your corporation at the expense of establishing, in ever expanding milieus, that corporations effectively have souls. As Richard Powers writes in his 1998 novel Gain, which is perhaps the first bildungsroman whose subject is a corporation, "He had lived long enough to see the constitutional amendment preventing any law that would abridge the privileges and immunities" of a corporation, "that legally created person. Such a law guaranteed the immortality dreamed of by the poets and prophets." In other words, the corporation is not just a legally created

Burwell v. Hobby Lobby Stores, Inc., 573 U.S. 682 (2014).

Richard POWERS, GAIN 181 (1998). Burkhard Schnepel notes that for the anthropologist Sir Henry Maine, the defining trait of

corporations, both sole and aggregate, is their perpetuity, assured by laws of intestate succession. Maine's maxim that 'corporations never die' puts the emphasis on the preservation and devolution of the collectively held universitas juris, the bundle of rights and duties . . . Fortes writes ... The point here is that it is not their co-existence as 'a plurality of persons collected in one body' that makes a group corporate, but their 'plurality in succession,' their perpetuity in time. Summing up these ideas [in The King's Two Bodies, Ernst] Kantorowicz says that "the most significant feature of the personified collectivities and corporate bodies was that they projected into past and future, that they preserved their identity despite changes, and that therefore they were legally immortal.

Burkhard Schnepel, Corporations, Personhood, and Ritual in Tribal Society: Three Interconnected Topics in the Anthropology of Meyer Fortes, 21 J. Anthropological SOC'y OXFord 1, 6 (1990). As such, these entities also can displace the cultural centrality of familial succession. Though his work is dated, and according to James Dow conflates the precepts of Maines and Max Weber and generated the "muddled concept of corporation in Anthropology," Fortes focuses on the critically overlooked ontological features of the corporation. James Dow, On the Muddled Concept of Corporation in Anthropology, 75 AMERICAN ANTHROPOLOGist 904, 905 (1973).

Corporate personhood also destabilizes what Michael Vicaro terms the

dualistic model of the self [that] is a central feature of philosophical liberalism. On one side of the liberal split-subject is the "private self," comprised of the unique particularities of one's corporeal and relational experiences; this private self is presumed to be inviolable and inaccessible to outside others but for the willfully consented to (and always imperfect) exchange of signs. 
person, but a legally created deity, as it is immortal and bears a host of super-human attributes that violate the laws of "nature." (It also displaces the poet of nature and prophet of religion). As Melville might say, corporations guarantee immortality to impersonality at the expense of mortal individuals, an exchange that creates an inverse relationship between corporate and personal freedom.

In his recent novel Glow, Ned Beauman proposes that "killing a corporation was like killing a colony of sentient fungus. . . . United Fruit was a hundred and eight. Chevron was a hundred and eighteen. De Beers was a hundred and twenty. Unlike governments, corporations endured: deathless, efficient, self-renewing." 8 This corporate immortality, and the expansion of exceptional corporate rights and immunities, is achieved at the expense of individual rights and identities. Throughout the work of Ralph Waldo Emerson-the antebellum American transcendentalist whose writing here provides a useful framework with which to assess the personhood of the corporation-Nature controlled a similar process, which he considered a form of divine dispossession. To attain immortality in Nature or in the corporate form, one must divest oneself of individuality.

This corporate displacement fulfills an arc Melville first traced in full in MobyDick, which emblematically situates the failing ubiquity of Nature against the rising ubiquity of the corporation. The leviathan of Moby Dick - a term Melville partly developed from Thomas Hobbes, to whom I return - represents, among other things, the demonological transition from the U.S. conception of Nature as an American provenance that serves to guarantee a universal natural law, to a conception of the transnational corporation that is everywhere the same. In that novel, Ishmael comes up against "the unearthly conceit that Moby Dick was ubiquitous; that he had been encountered in opposite latitudes at one and the same instant of time. ... [and] not only ubiquitous, but immortal (for immortality is but ubiquity in time"). ${ }^{9}$ Melville realizes that we have begun to inhabit a world where, as David Harvey notes, "two events in quite different spaces occurring at the same time could so intersect as to change how the world worked." 10 In this context, Moby Dick emerges as the first postmodern animal; seen in many places at once, it is everywhere the same, here still

On the other side stands the "public self," achieved by virtue of a process of "citizenly abstraction," by which the individual transcends private interests and becomes a representative of a rational community of impartial "stranger relations." The liberal individual thus maintains a natural, primary, and extra-discursive personhood, endowed with inalienable rights, and able through rational consent to take on temporarily on any number of subjectpositions and citizenly roles. The liberal citizen, for example, must abstract himself or herself from private interests and concerns to occupy the position of a soldier or a public official, but this is an identity position maintained through consent that can be revoked, thus returning one to a neutral and inalienable core self.

Michael P. Vicaro, A Liberal Use of 'Torture': Pain, Personhood, and Precedent in the U.S. Federal Definition of Torture, 14 Rhetoric \& Pub. AfF. 401, 414-15 (2011).

8 Ned Beauman, Glow 43 (2015).

9 Herman Melville, Moby-Dick; or The Whale 182-83 (Harrison Hayford, Hershel Parker, G. Thomas Tanselle, eds., 1988) [hereinafter referred to as $M D]$.

10 David Harvey, The Condition of Postmodernity: An Enquiry into the Origins of Cultural Change 265 (1990). 
like a franchise of Nature. In this image of a kind of quantum Moby Dick, which can be located in either time or space but never both simultaneously, Ishmael begins to chart the way American economies - of corporate whaling, manifest destiny, and masculine identity - set the stage for universal American corporations and products, but he still imagines a counter-force of transcendental Nature that remains equally and genuinely universal. (Douglas Rushkoff uses the terms "digiphrenia" and "fractalnoia" to describe the way digital media has now effectively trained us to be and see in many places simultaneously, but also synchronize too much data into patterns and reconcile incompatible states of mind). ${ }^{11}$ That process began as the nineteenthcentury corporation began to assert its universal identity, reach and influence in many places at once). Ishmael also specifically tells us "“It's a mutual, joint stock world, in all meridians," situating the corporation as the force already everywhere displacing Nature in a world increasingly defined by U.S. commerce. ${ }^{12}$ That joint-stock world must exist everywhere the same at once-in other words, it precisely takes over the function of the whale (nature) its corporate mission hunts to the brink of extinction.

In some ways unprecedented and anomalous in history, the corporation is a

11 Douglas Rushroff, Present Shock: When Everything Happens Now 96-97, 201-03 (2013).

12 See MD, supra note 9, at 62. Though manned by an Anarchasis Cloots convention of workers, The Pequod - from its Quaker financing to its role in the worldwide whale oil trade-also represents a distinctly corporate endeavor. Some critics rightly situate Starbuck as the epitome of rational commercial self-interest and Ahab as a figure who pathologically warps the profit motive (e.g., Paul Royster, Melville's Economy of Language, in IDEOlogy and Classic American Literature 322 (Sacvan Bercovitch \& Myra Jehlen eds., 1986)), but Ahab also serves partly as a heuristic for representing the monomaniacal corporate personality, and its narrow range of obsessive self-accretion. Ahab is not the exception that proves the rule, but an inevitable byproduct of the corporate enterprise, in much the way Kurtz in Apocalypse Now was not an aberration of the military ethos, but its apotheosis. What Herbert Marcuse described as the reductiveness of capitalism applies to Ahab and corporate personhood: "there is only one dimension, and it is everywhere and in all forms." Herbert Marcuse, One-Dimensional Man: Studies in the IDEOLOGY of Advanced Industrial Society 11 (1964).

According to the New Zealand novelist Ian Wedde, whose 1986 novel Symmes Hole develops an alternate history of the Pacific written as an extended corporate biography, Ahab's is the incipient corporate enterprise of U.S. imperialism:

No doubt about it, Captain Wilkes is Captain Ahab. ... And Wilkes had a brilliant megalomania before which the democratic American ethos quailed. ... But it gets even weirder. Wilkes was Ahab, and his backer was one of the spiritual fathers of American corporate vision protected by naval power. . . . behind the rapid debouchement of [Wilkes'] Great [Exploring] Expedition there lurks a shadowy . . . Rhode Island millionaire of the $1840 \mathrm{~s}$. . . and crank, one Jeremiah N. Reynolds [believer in the hollow earth, author of the original "Mocha Dick: Or the White Whale of the Pacific," and forbear of the R.J. Reynolds Tobacco dynasty] . . . [ [H]e must have had some vision of corporate structures bestriding the Pacific. . Reynolds wanted to get inside - and his descendants did: nuclear submarines and fast food. . . . the way was clear for enterprise that realized that corporate power loved the spaces between places just as much as the places.

Ian Wedde, Symmes Hole 152-54, 169 (1986). 
private institution that is everywhere, and everywhere precisely the same-and hence not only immortal, but ubiquitous. ${ }^{13}$ The franchise is one apotheosis of the corporate form; it is a kind of Platonic archetype that begins as an idea that is then reproduced endlessly to order. An infinitely replicable clone (or work of mechanical reproduction) without an original, the corporation can have the same identity always and everywhere, in some ways because it can have no identity at all, anywhere. In its modern form, it is already a purely digital/virtual/posthuman entity - without a body and yet omnipresent, existing in more than one place at the same time.

These initially maritime joint-stock companies, which settled the new world and for Melville were emblematized by the new global enterprise of whaling, were also intimately involved in all aspects of colonialism and the global slave tradethey were precursors of the modern corporation in many contexts. As Malick Ghachem notes, historians tend to assume the priority of the nation-state over such entities as the corporation as subjects of inquiry; but colonialism was advanced by conflicts between national trading companies as much as it was by disputes among the colonial powers themselves. ${ }^{14}$ (As Joseph Slaughter proposes in slightly different but relevant contexts in discussing Robinson Crusoe, oaths "are also the forms that colonial charter companies used not only to subjugate native peoples

13 The "residence" and "citizenship" of a corporation matters of course in the context of jurisdiction and local regulation. In what typically involved a race to the bottom, U.S. corporations began to incorporate in states, primarily Delaware, that offered not only the most comprehensive legal system, but the most permissive rules for incorporation and corporate liability and taxation. While some states, such as California, enacted legislation related to incorporation that would protect shareholders, most corporations could simply shop for better provisions elsewhere. But the state of incorporation is largely a fiction of locality and specificity, and another provision that allows for the kind of conceptual disconnection endemic to the corporate form; it has little bearing on where a corporation actually conducts its business or its ontological status as stateless. Many corporations that incorporate in Delaware, for example, simply maintain the equivalent of a post box there, without any attendant human presence.

14 Malick Ghachem, The Forever Company: How to Narrate the Story of an EighteenthCentury Legal Person (The Case of the Campaignie des Indes), Address Before the Legal Bodies Conference, Leiden University Centre for Arts in Society (May 17, 2014). Corporate names often reflect the conceptual and linguistic processes of capitalist mergers, which in perverse ways appear to imitate what capitalists often fantasize represents the Darwinian violence of nature. Chemical Bank, for example, takes over or cannibalizes Chase Bank, but retains the "conquered" name or vanquished logo as its company brand. In this variation of what Richard Slotkin terms regeneration through violence, the victorious corporation incorporates to itself through forms of sublimated and sometimes direct aggression. See generally Richard Slotkin, Regeneration Through Violence (1973). This conglomeration and aggregation of the corporate form often has been marked by an exploitation of nature, colonialism, and aboriginal dispossession. A logic of corporate invasion presides over a wide array of displacements and transfers, especially the displacement of what were once native inhabitants and species. The specifically joint-stock hunt for Moby Dick in Melville's novel, for example, takes place aboard a ship named after the exterminated tribe The Pequod. In consonant fashion, the corporation takes over the symbol of that which it has incorporated in its mergers and acquisitions, and the primary telos of the corporation is to commercialize, supplant and finally incorporate, figuratively and literally, nature itself. 
but also, in effect, to acquire international personality of their own"). ${ }^{15} \mathrm{~A}$ form of colonialism is inherent to aspects of the corporate enterprise, and the demands of capital, which seeks constant expansion into nature and other cultures associated with nature. In The Ticklish Subject, Slavoj Žižek contends that

The danger to Western capitalism comes not from outside, from the Chinese or some other monster beating us at our own game while depriving us of Western liberal individualism, but from the inherent limit of its own process of colonizing ever new (not only geographic, but also cultural, psychic, etc.) domains ... [until] Capital will no longer have any substantial content outside itself to feed on. ... [W] hen the circle closes itself, when reflexivity becomes thoroughly universal, the whole system is threatened. ${ }^{16}$

According to Ghachem, the only check on post-national corporate power comes in the language of fraud; unless an endeavor amounts to actual fraud, a corporation's rights and privileges are largely seen as a matter of right, not a reversible or temporary grant created by state charter. ${ }^{17}$ I argue that in the U.S., corporations began to supplant nation-states after they fully displaced Nature in the cultural functions they performed. The promethean state created the corporation that proceeded to subsume it. Nature was always a "transcendent" fiction of collective identity in U.S. culture, one that not only bore strong affinities with the corporation, but was ultimately revealed as its direct predecessor.

\section{Corporate Mergers and Corporate Animation}

To explain how the corporation emerges as the successor to or fulfillment of transcendental Nature, I here briefly address pantheistic (primarily) American writers who, perhaps unexpectedly, served as precursors to and harbingers of contemporary corporate culture. The type of transcendentalists most concerned with the collective and impersonal aspects of Nature, pantheists evoked its attributed power, scope, and functions in ways that consistently comport with the same vectors of the "animated" corporation. Many pantheistic depictions of merger with Nature either predict or are co-opted by the corporate age that soon follows. For example, in All Is One: A Plea for the Higher Pantheism, Edmond Holmes describes the fall of man from nature:

The animism [that] peopled the outward world with nature spirits was the instinctive protest of man's heart against the materialism of his conscious thought. . . [When] animism fell into disrepute . . . . it made possible [] scientific exploration .... [but] as belief in the supernatural waned

15 Joseph R. Slaughter, However Incompletely, Human, in The Meanings of Rights: THE Philosophy and Social Theory of Human Rights 287 (Costas Douzinas \& Conor Gearty eds., 2014).

16 Slavou Žižek, The Ticklish Subject: The Absent Centre of Political Ontology 358 (2000).

17 Ghachem, supra note 14. 
... . especially in Protestant countries . . materialism reject[ed] the supernatural, and [gave] a mechanistic explanation of life .... [the loss of animism]. . . empt[ied] nature of her own spiritual life. ${ }^{18}$

The corporation both disembodies and reembodies this lost spiritual animism in the guise of a mechanical, mechanistic and deterministic artificial life, overlaid with a human face and soul. In his 1885 address to the Concord School of Philosophy, John Fiske asserted that everything in the world is animated or alive:

[T] he universe as a whole is thrilling in every fibre with Life,- - not, indeed, life in the usual restricted sense, but life in a general sense. The distinction, once deemed absolute, between the living and the not-living is converted into a relative distinction; and Life as manifested in the organism is seen to be only a specialized form of the Universal Life. . . . reappearing from moment to moment under myriad Protean forms .... [through] this animating principle of the universe. ${ }^{19}$

This specific process of animation is a kind of predicate for being imbued with a soul; for transcendental pantheists, all things have souls because Nature, in some impersonal way, is itself a living personified entity. But we will see this ascription of soul transfer to the animation and personification of the corporation.

Transcendentalists believed that some mysterious, ubiquitous principle or force infused universal Nature and also "animated" all people, representing an impersonal annexation of the personal. Such animation or life could not be restricted to people, or even organic matter; as Melville suggest throughout his novel Mardi, the entire world is alive, and has a soul. Animation is the principle of transcendental Nature that guarantees and connects all life, and renders all life equivalent: "With Oro [Pan], the sun is coeternal; and the same life that moves that moose animates alike the sun and Oro." ${ }^{20}$ Babbalanja's description of his world of Mardi offers a blueprint for imagining an entire world that is a collective Being:

I live while consciousness is not mine, while to all appearances I am a clod. And may not this same state of being, though but alternate with me, be continually that of many dumb, passive objects we so carelessly regard? Trust me, there are more things alive than those that crawl, or fly, or swim ... . Think you it is nothing to be a world? . . what are our tokens of animation? ... Think you there is no sensation in being a rock? ${ }^{21}$

Consciousness here becomes potentially fungible or transitive, and Nature in effect serves to guarantee our continued existence, to bridge lacunae in consciousness and identity (in ways that adumbrate the function of the corporation). "Animation" is what turns mere matter into an entity characterized by some form of life, but

18 Edmond Holmes, All Is One: A Plea for the Higher Pantheism 16-17 (1921).

19 John Fiske, The Idea of God As AfFected by Modern KNowledge 149-51 (1899) (1885).

20 Herman Melville, Mardi and a Voyage Thither 615 (Harrison Hayford et al. eds., 1970) (1849).

${ }_{21} \quad I d$. at 458 . 
without the intervention of an anthropomorphic deity. Adumbrating Mardi, James Russell Lowell complained of Emerson's Divinity School Address that he would not "hear the anointed Son of God/Made like themselves an animated clod." 22 Under the extended terms of such debates, the corporation itself comes to be animated and possess a form of consciousness.

For transcendentalists and some political theorists, Nature once served as the universal force that authorized American democracy (as well as manifest destiny). But as the nation-state came to be unified not by Nature-which was imagined to be everywhere the same-but corporate technologies such as the railroad and telegraph, the corporation became the new animated clod. A key question, since transferred to the corporation, is what kind of speech animated Nature could make. Emerson believed that "The Soul which animates nature is not less significantly published in the figure, movement and gesture of animated bodies, than its last vehicle of articulated speech .... A statue has no tongue, and needs none." "As Hawthorne writes in The Marble Faun, Americans easily are seduced by "the mystery, the miracle, of imbuing an inanimate substance with thought, feeling, and all the tangible attributes of the soul." ${ }^{24}$ As if lamenting the disappearance of the Mardian world of animated nature, the contemporary American naturalist Annie Dillard asks, "Did the wind use to cry, and the hill shout forth praise? Now speech has perished from among the lifeless things of earth, and living things say very little to very few." ${ }^{25}$ (As I begin to argue in "Not Altogether Human": Pantheism and the Dark Nature of the American Renaissance (2012), the animated corporation voices this now silent speech of Nature, and comes to serve as the centralized repository of collective speech, souls, and even life itself in the U.S. ethos). In the transcendental American grain, Nature was an often personified social construct, or fiction, that has an alleged intent and animates people. Ironically, as the corporation comes to assume the functions of Nature, it is supported by an ever-increasing array of technologies that enable it to simulate and transcend the ubiquity of natural forces.

The law itself once situated corporations as artificial constructions that mimicked nature. Some twentieth-century legal cases, for example, specify that the state animates corporations: "A corporation is a creature of the State. It owes its very being to the State. "Into its nostrils the State must breathe the breath of a fictitious life for otherwise it would be no animated body but individualistic dust [citation omitted]." ${ }^{26}$ Such cases appropriately still treat the corporation as a kind of closelyheld Frankenstein's monster, an animated thing of dust: "While the directors are chosen by the stockholders, they become, when elected and properly organized as a board, the agent of the corporation. It is by such means that animate force is

\footnotetext{
22 John J. McAleER, Ralph Waldo Emerson: Days of EnCounter 250 (1984).

23 VI, Ralph Waldo Emerson, Behavior, The Complete Works of Ralph Waldo EMERSON VI 169 (1904) [hereinafter referred to as WORKs].

24 IV, Nathaniel Hawthorne, The Marble Faun: Or, The Romance of Monte Beni, in The Centenary Edition of the Works of Nathaniel HaWthorne 271 (William Charvat, et al. eds., 1968).

25 Annie Dillard, Teaching a Stone to Talk 69 (1982).

26 Cloverfields Improv. Assoc. v. Seabreeze Props., Inc., 32 Md. App. 421, 425 (Md. Ct. Spec. App. 1976).
} 
given to an inanimate thing. ${ }^{27}$ Contrary to most representations of corporations in films and texts, these courts treat the corporation as having no independent life at all, and as a mere contrivance: "Corporations are animated by people; those who control such corporations hire others to perform on the corporation's behalf." 28 This language modifies the descriptions found in text as such as Mardi in addressing the ways people and things manifest agency (and the natural and artificial signs of life), but the reality is that corporations are no longer animated people and states, but the reverse. As we shall see, cases have increasingly reified the fiction of the corporation as an animated person or entity unto itself.

After Lukács, Michael Rogin proposes that "every cog is human; when power is attributed to emblems, and they do human work, the writer has succumbed to animism." ${ }^{29}$ Transcendental animism - the rhetoric that attributed life, personality and soul to aspects of Nature - was transferred to the corporate form. ${ }^{30}$ According to Gregory A. Mark, the idea of a corporation imbued with life did not hold great influence in the United States: "Equally ill-fated were the attempts to animate the corporation, which were not generally taken seriously in America. Nonetheless, commentators recognized the births and deaths of corporations, and accepted that they possessed lives and the powers to will, to act, and to create." ${ }^{31}$ But I would argue that this idea of animation, even if not taken seriously in the general culture until recently, has had profound ramifications and effects and is an indispensible facet of a religious and ontological discourse that pervades U.S. culture. Party as an outgrowth of the legal separation between corporate tortfeasor and individual liability, the corporation has come to possess a life of its own precisely independent of the people who allegedly animate it.

Disturbingly, some posthumanist and neo-vitalist theory, which tries to erase hierarchical distinctions between species and organic and inorganic matter, can

Lamb v. Lehmann, 143 N.E. 276, 278 (Ohio 1924).

Chemtall, Inc. v. Citi-Chem, Inc., 992 F. Supp. 1390, 1403 (S.D. Ga. 1998).

Michael Rogin, Subversive Genealogy 115 (1983).

30 Though I don't have space to develop the claim here, I argue that Avatar unwittingly dramatizes the ways corporate personhood is predicated on commensurate discourses of primitivism and fetishized technology; its false opposition between the militarized mining corporation and the pantheist/animist tribe is dismantled not only by the overdetermined issue of incorporation - the fact that humans on Pandora can interact with nature only by assuming virtual bodies - but the fact that their access to this nature is purely virtual. They jack into computers the same way the Navi access their horses and other animals, with various forms of USB plugs. The film lays bare the pretense that humans can oppose a corporate culture by aligning themselves with a primitive tribe/ living world - precisely Melville's narrative in Mardi, whose living planet is an early version of Pandora. Perhaps unwittingly, the film exposes nature as having been always already a social/corporate/ virtual construct.

As if addressing Avatar, Žižek contends that "This new notion of life is thus neutral with respect to the distinction between natural and cultural (or 'artificial') processes - the Earth (as Gaia) as well as the global market both appear as gigantic self-regulated living systems." Slavoj Žižex, Interrogating the Real 85 (Rex Butler and Scott Stephens eds., 2006) (2005). In this new-age fantasy of cyberspace, we leave real bodies behind and become corporate or cyber bodies that efface nay remaining distinctions between nature, technology, and corporation.

31 Gregory A. Mark, The Personification of the Business Corporation in American Law, 54 U. CHI. L. Rev. 1441, 1473-74 (1987). 
play into the notion that the corporation is itself alive, and has personhood, rights, and a soul. For example, under Roberto Esposito's resuscitation of vitalismwhich echoes antebellum pantheism, contends that all life is equal and should be approached impersonally, and is meant to transcend the limitations of the human/ humanism - the impersonal corporation could also be considered alive. ${ }^{32}$ Here, posthumanism can be used to advance the interest of the posthuman corporation, and the corporation, in precisely structural/impersonal terms, is effectively able to appropriate posthumanist personhood as, we shall see, it did the personhood of African Americans. Similarly, Jane Bennett's notion of enchanted matter, impersonal affect and heterogeneous/ distributive agency could also apply to the same kind of animism that gives corporations the ontological status of persons. ${ }^{33}$ To deny the distinction between the living and the non-living can play directly into the absent hands of the corporation. Such theorists sometimes confuse the impersonal, which they tether to a rights discourse, with the egalitarian; the excesses that can mar personal discourses do not warrant their abandonment, but regulation.

In the United States, the history of the corporation also tracks the shift from romanticism to naturalism and back to neo-romanticism, all of which, perhaps surprisingly, maintain many of the same premises regarding the aggregate forces of Nature/the corporation, and primarily shift only their reaction to those premises. Under naturalism, nature represents an impersonal automaton, an emblem of brute/ blind force. Yet as Walter Benn Michaels suggests - through the "discrepancy between the behavior of individuals and that of the aggregate"-Nature ultimately can turn everything into (and problematize the very notion of) a person: "dreaming of the "monstrous," [Frank Norris'] Presley [in The Octopus] is already dreaming of the corporation." ${ }^{34}$ Here, impersonal transcendental Nature, which represents an aggregate mass, serves as a precursor to Norris' impersonal and effectively transcendental corporation - in this trajectory, the leviathan has turned into another large sea-kraken, but with more outreach.

\section{The Corporate Person}

Beginning with Hobbes, the teleology of the corporate form would take it from being a surrogate for a deified Nature and "centralizing" nation-state to being their successor or near-successor. Melissa Aronczyk observes that corporate advertisers and branding agencies now legitimate and maintain the nation-state as one of our primary cultural reference points..$^{35}$ However, the corporation has in some ways overtaken the nation-state as the most significant producer of laws and cultural signifiers. (Jorg Kustermans argues that the nation-state also effectively utilizes its legal status to claim personhood, in a form of republican identity-construction comparable to the construction of individual personhood, but I would argue that

32 See generally Roberto Esposito, Bíos: Biopolitics and Philosophy (Timothy Campbell trans., 2008) (2004).

33 See generally Jane Bennett, Vibrant Matter: A Political Ecology of Things (2010).

34 Walter Benn Michaels, The Gold Standard and the Logic of Naturalism 211 (1987).

35 Melissa Aronczyk, Branding the Nation: The Global Business of National IDENTITY 64-65 (2013). 
it is critical to differentiate formulations of individual personhood from those of aggregate personhood). ${ }^{36}$ In the twenty first century, nation-states often fragment or become engaged in civil, sectarian, religious and postcolonial wars-corporations, by contrast, tend to consolidate and expand. As John Meyer and Patricia Bromley remark in addressing the recent rise of organizations generally world-wide, "An overarching explanation is that the dramatic limitations of the nation-state system, especially two horrific world wars, undermined government-based control, [thereby] creating supports for alternative forms of a more global social order." ${ }^{\prime 37}$

In the next section, I focus briefly on Richard Powers' novel Gain because it offers insights into the idioms of corporate biography, and provides a useful bridge from my preceding discussion of nature to the subsequent section addressing corporate agency and personhood. Gain presents a Joycean history of advertising language as it evolves from the familial and personal to the corporate. Literalizing the concept of the corporate legal fiction, Powers presciently wrote a biography of what emblematically began as a soap company as it regressed from the Revolutionary period to become a kind of postmodern golem. (Selling soap of course became the virtual signet of early television advertising, the quintessential mechanism for sponsoring content). Tracking the way the Clare Corporation produces increasingly deleterious products, Powers' narrator develops a biographical ontology and corresponding language that become ever more "corporatized" as they near the present. As it spans several hundred years, and businesses become more corporate and advertising more pervasive, the novel grows more impersonal in its precepts and characterizations; it is as if a roman à clef turned into a CGI biography scripted by an algorithm. Joseph Dewey suggests "the narrative of Clare International reads like an absorbing - and convincing-history." ${ }^{38}$ But Paul Maliszewski believes Gain shifted its focus from personal history to what I would term a kind of corporate common law: "Powers read stories of real corporate characters and companies like Proctor \& Gamble, Colgate and Lever, and found their stories Shakespearean. But the personification of Clare and its central role in the novel is less a matter of poetic than corporate law." 39 What Powers narrativizes is that the corporation takes over-

36 See generally Jorg Kustermans, The State as Citizen: State Personhood and Ideology, 14 J. INT'L ReL. \& DEv. 1 (2011).

37 John W. Meyer \& Patricia Bromley, The Worldwide Expansion of "Organization," 31 Soc. THEORY 366, 368 (2013).

38 Joseph Dewey, Understanding Richard Powers 110 (2002).

39 Paul Maliszewski, The Business of Gain, in InTERSECTIONS: EsSAYS on Richard Powers 167 (Stephen J. Burn \& Peter Dempsey eds., 2008). Though the issue is outside the scope of this essay, one should consider how corporations foster the erosion of privacy in contemporary U.S. culture - the hyper-voyeurism of contemporary reality TV and corporate journalism downplay facts, and promote forms of exposure, envy, schadenfreude and competition that are predicated on making the private public. In such contexts, Powers (along with Wallace) intimates that the corporation has ruined the genre of the novel, its language and epistemological ability to convey aspects of human interiority. The corporate formula becomes the formula for life-writing, and even reading. To redefine and "corporatize" individuality, corporations rely on conventions similar to those of Reality TV - archetypes, selves identified with/as generic competitive tropes, and an effectively medieval notion of identity (characters that are little more than drives, and simply personify vices such as envy). That strategy is exemplified and laid bare in the parodic but emblematic commercials that pretend to be mini soap opera 
not only the town, but the idea of family, the bodies of its workers and consumers, and the precepts of narrative itself.

As David Foster Wallace intimates throughout The Pale King, the problem isn't just that contemporary corporations are treated as if they were people, but that people start behaving as if they were corporations. ${ }^{40}$ For Wallace and Powers especially, corporations represent the denouement of a strain of biographical fiction - they emblematize a kind of dead-end, what George Steiner might consider the dissolution of an old and (putatively) communal cultural literacy, which is replaced by an ever more dominant corporate culture. By the end of the last millennium, Clare's "ads provided the backbone of shared culture, from playground to dinner table. ... Old Native Balm engravings now went for thousands of dollars at auctions. A novelization of a series of commercials for Clare's leading over-thecounter painkiller ran for twelve weeks on the New York Times best seller list, and even made money as a film." ${ }^{41}$ Writers such as Powers, Wallace and Don DeLillo dramatize the subordination and powerlessness of culture, of the biographical novel, when displaced by the life-writing, personhood and cultural influence of the corporation - these truths are not only stranger than fiction, they replace it.

Maliszewski cites Powers' own impression that "the literary approach" to business, which relies on humanist principles and characters to dramatize corporate systems, has become inadequate, and led him to pursue an articulation of the impersonal. ${ }^{42}$ In other words, the old constraints of fiction prevent it from being able to apprehend the new contrivances of corporate fiction. Powers explicitly proposes that "the corporate protagonist's cycle of boom and bust [is] substituting for a narrative's rise and fall." ${ }^{\prime 3}$ Powers' narrator then tells us, "with the right corporate structure, decisions practically handled themselves": that is, human agency, along with many of the very structures of narrative and biography and the human life cycle, recede or even disappear into impersonal discourse, and the recycling and inhuman cadences of corporate life cycles. ${ }^{44}$ Such fictions narrativize not just an invisible hand, but the development of an entire corpus that is non-existent; in other words, we are left with decisions without decision-makers, shadows without casters, impersonators without persons.

Beginning with their Hobbesian chartered inceptions, corporations have always been artificial entities imbued with personhood, or souls. The deafening, largely unregulated speech they make in most contemporary societies is perversely proportionate to the absence of an identifiable speaker (behind the spokesperson) ultimately, theirs is speech without an individual orator or source, but it generates a discourse that permeates everything. As Maliszewski notes, in Gain the protagonist's central mission is to discover the corporate source of her cancer, but no

dramas: the product (and product narrative) is intended to displace not just the person, but human personhood. Self-important "serious" ads now often rely on short attention span family dramas (barely-averted accidents, children growing up, break ups, break ins, etc.) that use products as placeholders for life events and relations. This corporatization of human affect warps narrative, biography, cultural literacy and most habits of reading. David Foster Wallace, The Pale King (2011).

POWERS, supra note 7, at 340-41.

Maliszewski, supra note 39, at 166.

POWERs, supra note 7, at 166.

$44 \quad$ Id. at 288. 
personal agency, no person, exists to be found. ${ }^{45}$ The emblem for that contemporary corporation should be the unpersoned drone (whose recent emergence seems not accidental, but an outgrowth of assumptions related to corporate governance, responsibility and rights). Further, the biography of a corporation would be a close cognate of the biography of an unpersoned drone. Robert Mankoff, a New Yorker cartoonist, depicts God declaiming that "Switching to drones has made having to be everywhere at once much more manageable." ${ }^{46}$ Here representing a kind of technonecrotic "evolution" of Moby Dick, the drone that is everywhere at once is in some ways an appropriate mascot for the corporation: it elides agency and liability; is part of a tangled network of corporate profits and governmental/military collusion; and creates another nexus for a kind of corporate management of life and death. Unpersoned is a word that describes the effect of corporate culture on individuals, but also on social values. If we are becoming posthuman, we are also becoming unpersoned.

For Powers, well before the Citizens United case, infra, corporations had achieved personhood by hijacking the rights or privileges of persons, and specifically by co-opting the emancipation of slaves: "If the Fifth and Fourteenth Amendments combined to extend due process to all individuals, and if the incorporated business had become a single person under the law, then the Clare Soap and Chemical Company now enjoyed all the legal protections afforded any individual by the spirit of the Constitution." ${ }^{47}$ As Powers contends, the corporation represents "an ingenious device for obtaining individual profit without individual responsibility. ... He might have found the explication, clever, funny, perhaps even diabolical, if it weren't the absolute letter of the law." In this institutionalized fantasy-which represents a kind of collective return of the repressed - the law declares any corporation "one composite body: a single, whole, and statutorily enabled person." ${ }^{48}$ Under a form of demonological logic, the once fragmented body of the statutorily disenfranchised slave - who was defined by the Constitution as being worth $3 / 5$ of a person-is "unified" or, as Toni Morrison might say, re-membered in the collective, single super-body of the impersoned corporation.

But in the ontological and practical economic aspects of the zero sum game of personhood, corporate enfranchisement was gained at the expense of the disenfranchised. African-American slaves were freed and became legal persons under the aegis of due process, but corporations, the greater Elvis, effectively appropriated those rights. Corporations asserted they too had the rights of natural persons under the Fourteenth Amendment (petitions that have since grown into claims of aggregations of super rights, which allow corporations, in terms of reach and effect, to broadcast what are in effect millions of voices in their own names). Instead of being fractions of people, corporations became composites of all people. But African Americans had to invoke the rights of corporate persons to enforce their civil rights; they were able to challenge segregation under Heart of Atlanta Motel Inc. v. United States, not because it was illegal to discriminate against black people as persons, but because it was illegal to interfere with interstate commerce

\footnotetext{
Maliszewski, supra note 39, at 163.

46 Robert Mankoff, Switching to Drones Has Made Having to be Everywhere at Once Much More Manageable, The New Yorker, Sept. 23, 2013, at 56.

47 Powers, supra note 7, at 159.
}

48 Id. 
(specifically with black truckers seeking food and shelter while traveling in the segregated South) under the Commerce Clause. ${ }^{49}$ Pilfering the personhood that African Americans had finally achieved, corporations also unwittingly appropriated and ironicized the term soul-brother. (This scenario perhaps represents the most egregious instance of a corporation stealing soul). The corporate strategy reflects not only a necessary legal tactic/feint to achieve an end; it initiates another move in the escalating zero sum game of corporate personhood. ${ }^{50}$

49 Heart of Atlanta Motel, Inc. v. United States, 379 U.S. 241 (1964).

50 Responding to a challenge to the Civil Rights Act in 1964, for example, the Court stated that "Section 201 (a) of Title II commands that all persons shall be entitled to the full and equal enjoyment of the goods and services of any place of public accommodation without discrimination or segregation on the ground of race, color, religion, or national origin; and $\S 201$ (b) defines establishments as places of public accommodation if their operations affect commerce or segregation by them is supported by state action." Katzenbach. v. McClung, 379 U.S. 294, 298 (1964). In effect, the Court had to address the district court's assertion that it was required to find a "demonstrable connection between food purchased in interstate commerce and sold in a restaurant and the conclusion of Congress that discrimination in the restaurant would affect that commerce." Id. at 297. Partly because of precedent, the Court effectively decided that it could uphold the civil rights law only on the grounds that discrimination cumulatively affected interstate commerce. For example, addressing a civil rights law in the nineteenth-century, the Court had pronounced that "the first and second sections of the . . "Act to protect all citizens in their civil and legal rights," are unconstitutional and void." Civil Rights Cases, 109 U.S. 3, 26 (1882). According to the Court, "The essence of the law is, not to declare broadly that all persons shall be entitled to the full and equal enjoyment of the accommodations, advantages, facilities, and privileges of inns, public conveyances, and theatres; but that such enjoyment shall not be subject to any conditions applicable only to citizens of a particular race or color, or who had been in a previous condition of servitude." Id. at 9-10. In other words, congress did not have the right to legislate equality per se, especially proactively and with regard to individual persons:

Has Congress constitutional power to make such a law? . . It is absurd to affirm that, because the rights of life, liberty and property (which include all civil rights that men have), are by the amendment sought to be protected against invasion on the part of the State without due process of law, Congress may therefore provide due process of law for their vindication in every case; and that, because the denial by a State to any persons, of the equal protection of the laws, is prohibited by the amendment, therefore Congress may establish laws for their equal protection. In fine, the legislation which Congress is authorized to adopt in this behalf is not general legislation upon the [civil] rights of the citizen, but corrective legislation ...

Id. at 13. Even in the 1960s, the Court had to defer to a perceived lack of congressional authority to address issues of personal/civil rights as issues of human rights rather than, implicitly, as proto-corporate issues of commerce. 


\title{
PART Two
}

\section{The Two Sovereign Problem}

\begin{abstract}
"We have to take the power back from the Parliament and put it where it belongs."

"With the East India Company?" I proposed.

"That is exactly right: with the East India Company, and the chartered companies, and those men of wealth and ingenuity who wield the power in our economy. To them must go the spoils of the earth, not members of parliament."
\end{abstract}

David Liss, The Devil's Company ${ }^{5 l}$

The history of the corporation is closely connected to the history of the modern state, the abstract collective that provides an aggregate identity to those who belong to it or live under its field of influence. Hobbes could guarantee the continuity of the state by making it an impersonal entity that traversed the lifespans and limitations of individual rulers; the state was represented by particular sovereigns or men, but they were in a critical sense mere placeholders. Similarly, the corporation becomes an impersonal structure, precisely divorced from its owners or employees, who are not only temporary, but, in relative terms, fungible. Like the nation-state, the corporation is an impersonality we are in service to, but one that ultimately displaces and supplants its subjects; it is as if we have ended up as hosts to the impersonality, which has become more virulent, resistant, and embedded over time.

It is important to consider the relationship of the corporation, the current body of power in society, to its antecedent forms, particularly the bodies of Nature and the king. The corporate body retains but transforms the mystical and inhuman properties associated with the king's body; as with a sovereign body, it represents a conjunction of an extra-human body and an exceptional or non-human personality (though many now would allege that the king and corporation also are equally persons). Aggregate and symbolic bodies of power typically bear contradictory or mystical attributes. In many cultures, for example, "It was not proper to refer to [the king's] body or to imply that he had an ordinary human body at all. A special word was used instead, signifying the kingly personality." ${ }^{2} 2$ Ironically, whereas "the crucial thing about the king is his uniqueness," the crucial thing about the modern corporation is its ubiquity and uniformity-it champions apparent uniqueness through its brute universality. ${ }^{53}$ In the corporate state, the function of this collectivized body is still to represent power-but in the corporation it is stripped of the specific overlay of human personality (except as manifested in the ventriloquism of advertising).

Yet as Žižek might argue, a corporate figurehead typically must be created through a process of fetishization and reification, or

51 David Liss, The Devil's Company: A Novel 118 (2009).

52 Elias Canetti, Crowds ANd Power 414 (Carol Stewart trans., 1973) (1960).

53 Id. 
the "false 'personalization' ('psychologization') of what are in fact objective social processes. It was in the 1930s that the first generation of Frankfurt School theoreticians drew attention to how-at the very moment when global market relations started to exert their full domination, making the individual producer's success or failure dependent on market cycles totally out of his control - the notion of a charismatic 'business genius' reasserted itself in 'spontaneous capitalist ideology,' attributing the success or failure of a businessman to some mysterious je ne sais quais which he possesses. ${ }^{54}$

Though this is a valid observation, it will perhaps come across as an exaggeration in some instances, in that CEOs such as Steve Jobs, sometimes in actuality rather just public perception, do exert significant (or virtually monopolistic) control over their corporations. But such charismatic personalities do not change the categorical nature of corporate personhood: the business leader serves to naturalize the notion that some person stands behind corporate personhood. The law transposes the relationship between persons to, or imposes it on, impersonal forces that annul personhood.

Hobbes' work remains critical for understanding the artificial person of the corporation and its relation to bodies - bodies of power, science fiction bodies, and dematerialized bodies. In political as well as sociological contexts, the corporation has become a less accountable version of the absolute sovereign, as well as the embodiment of actorhood and agency, Hobbes imagined that the state had to be. Beyond a king, the corporation is both hyper-embodied and disembodied. That erstwhile disembodiment of course does not diminish the materiality of the corporate form, even as a legal fiction, or its effects; that putative "immateriality" is a construct that serves to bolster and shield corporate power. ${ }^{55}$ For Michaels, the possibility of a corporate person/personality without a body represents a form of idealism or fantasy - one, I would add, that further removes the corporation from the world of lived reality to the world of the sublime or numinous horror. ${ }^{56}$ Michaels observes that "Whereas in a partnership, the death of a partner dissolves the partnership, in [the view of Josiah] Royce [the philosopher of American corporate life], no physical event can jeopardize the life of the corporate entity-its soul is immortal. ${ }^{\circ 7}$ The corporation begins as a figurative, culturally-constructed body, but ends as a disembodied everlasting soul, and that trajectory remains related to U.S. conceptions of the materiality of collective Nature. The corporation and Nature are both fictions that we embody and reify, and to which we give a shape, characteristics, and even voice. (This premise also helps explain the narratives of some reflexive mysteries; because we must ventriloquize the dumb corporation and project its essence - the mysterious voice we cannot identify - the agents/actors of crimes we cannot trace or account for often turn out to be not just corporate malefactors, but us all along. The detective/analyst often seeks himself, and in the

\footnotetext{
ŽıžEK, supra note 16 , at 49.

55 I develop my argument about the materiality of the corporation, and the corporate use of nature as camouflage, more fully in New and Improved: The Zero-Sum Game of Corporate Personhood (book in progress).

56 Michaels, supra note 34, at 189.

${ }^{57}$ Id. at $188-89$.
} 
context of social "mysteries," corporations often serve as a screen for enacting our repressed social unconscious. In Lacanian terms, when we hear the corporation speak, it is our voice we are hearing, or getting back, distorted).

The corporation fulfills one particularly American cultural fantasy regarding the transcendence of materiality. The goal of Emerson's transcendentalism is to transcend both individuality and the male body - to merge into Nature, into the blithe air itself, and become a transparent eyeball that is nothing, but sees everything. Seeking to experience Nature as a disembodied and unobserved observer, Emerson wants to become invisible and immaterial, yet omnipresent. We can also transcend that self in the corporation, which is a form of virtual embodiment that, through the oxymoron/fiction of incorporation, generates an artificial person that has no body. As one of David Foster Wallace's characters in The Pale King observes, "Doesn't the term corporation itself come from body, like "made into a body"? These were artificial people being created." 58 In the ulterior logic of our culture, pervasive forms of artificial intelligence and artificial life are now also identified with the virtual and the post-human, and all these categories with the corporation. In addition, speculating on the future has become closely allied with the corporate form, which transcends individual life by creating a fictional, artificial being that never dies, never transmits an inheritance, and so forth - a monstrosity that is ubiquitous and yet locatable nowhere. True to its designation, the corporation is an animated corpse, an undead body imbued with artificial life that haunts our civilization. I argue elsewhere that contemporary representations of inhuman lifeincluding zombies, aliens, and forms of altered or collective, but unintelligible, sentience - often bear a corporate residue because they reflect our anxiety not simply that corporations are creating alien forms of life, but that they reflect and have instigated the ways our own lives already have become alien and inhuman.

The modern form of the corporate enterprise also performs many of the precepts of poststructural semiotics-for example, it advances a deliberate disconnection of act/speech from source/intention. In most contexts, we have corporate signifieds, and, both legally and ontologically, no signifiers of a different sort-no one responsible for them legally or culturally. In symbolic and practical ways, as DeLillo intimates throughout Mao II, the corporation is, in dialectical fashion, both a cause and effect of the symbolic death of the author in our culture. The early twentiethcentury populist orator Cyclone Davis asserted that he "would not be surprised to hear that some man had invented a machine for making books that dispensed with [the] author ... and ground out paragraphs by steam." 59 The corporation relies on numerous machines that dispense with authors, or people altogether, effectively validating the poststructuralist notion of a text without an author, but also of the corporation itself as the ultimate author function. As I argue in a different context in New and Improved, the teleology of corporations is to dispense with people not just in their modes of production, but their organizational ontologies; their ultimate form of growth is to accrete the personhood of those who serve them. Lars Christensen and George Cheney propose broadly that all contemporary organizations, regardless of their sector, "are in the communications business," and that corporations generate their identities less through sales than messaging. ${ }^{60}$

58 WaLlaCe, supra note 40, at 140.

59 MiChAELS, supra note 34, at 209.

60 Lars Thøger Christensen \& George Cheney, Self-Absorption and Self-seduction in 
But I also would contend that corporations are not primarily communicating about products or even themselves: they are communicating, performing and proliferating an epistemology and ontology, and in this sense also serve as our last Big Others, systems without centers, disquisitions without speakers, constellations of effects and processes without causes or affects.

\section{The Artificial Person}

As we can see in many Hollywood films, some forms of such corporate ventriloquism are connected to anxieties regarding possession and dispossession: for example, the dead that colonize life, and speak through and inhabit us. The undead and the many forms of artificial or altered beings that look as if they were alive, but only imitate life, often have some affinity with the corporate person. What Hobbes describes as the artificial person of the corporation in part evolves into a form of artificial intelligence, embodied in the various science fiction and horror film impersonations of the human form. Aside from the fact that some corporations rely heavily on technologies that simulate and even replace life, and what we might term a myriad of reality simulators - from games to movies and Japanese sex robots - impersonated forms of reality are typically produced by, and are unnatural allies of, corporations because they all involve imitations of life. (Benjamin Sovacool argues that the corporation itself has emerged as an unrecognized form of instrumentally successful, but socially failing, technology). ${ }^{61}$ The novelist Philip K. Dick became fascinated by Alan Turing's experiments to evaluate whether we can verify what it means to be human: specifically, whether machines can think, or convince us they are thinking, or, when not present, that they are actual human beings. ${ }^{62}$ Turing's postulate was that something is human if it can convince another human it is. That assertion raises the question, how does the person doing the comparison know it is itself human? The corporate person is a quintessential generator and example of artificial intelligence. Dick's litmus test for a human being, however, was not whether it could convince a person it was human, but whether it possessed empathy, ${ }^{63}$ a test a corporate person would fail, because it is programmed by law to care about profits above anything else. People almost have universally feared that some supernatural force or version of the devil could impersonate the human form. Our concern that we can no longer isolate or differentiate human from inhuman cogitation has of course increased with our reliance on virtual realities and internet communication, a world run by computers. Our fear now is not only that a corporation can impersonate the human form, but that the human form has become obsolete, and now impersonates the corporate form.

The characteristically artificial personhood of the corporation should now be situated in the context of the artificial world of simulations and computers, but also

the Corporate Identity Game, in The Expressive Organization: Linking IDENTITY, Reputation and the Corporate Brand 247, 249 (Majken Schultz et al. eds., 2000).

61 Benjamin K. Sovacool, Broken by Design: The Corporation as a Failed Technology, 15 SCI. TeCH. \& SOC'y 1, 2-5 (2010).

62 Emmanuel Carrère, I am Alive and You Are Dead: A Journey into the Mind of PHiLIP K. Dick 132 (Metropolitan Books 2004) (1993).

$63 \quad I d$. at 135. 
of the collective body of the state-itself a kind of foundational science fiction motif. As Sharon Cameron summarizes the Hobbesian lineage of personhood,

\begin{abstract}
The word person confers status (designating a rational being in distinction to a thing or an animal), value, even equality; it establishes intelligibility within a political and legal system, indicating a being having legal rights or representing others' rights, either because he is a human being or natural person or because he is a corporate body or artificial person. (For Hobbes an artificial person must also be a natural person.) It does not, however, presume anything of substance, nor did the word persona from which it derived. A persona was never essential, since a persona is not an actor but the mask which covers the actor, or the character who is acted. . $^{64}$
\end{abstract}

But Cameron partly misrepresents Hobbes in this context: Hobbes does not believe artificial persons also must be natural persons, only that they must be represented by agents who are natural persons. However, Hobbes does begin to erode the distinction between natural and unnatural in ways that prepare for the modern corporation. What he did not quite anticipate was that the leviathan of the state would give way to the far less "natural" leviathan of the corporation.

\title{
III. THE NeW LEVIATHAN
}

The legal creation of personhood made it possible to redefine human identity within the confines of the nation-state; ultimately, we could take personhood away by treating someone as a thing, or, conversely create personhood by treating a thing as if it had personal attributes and rights. In other words, if we begin with a definition of personhood that situates the concept as not simply constructed, but pointedly artificial, it is almost inevitable that our other institutions, such as corporations, will be defined under similar coordinates. Hobbes begins the subordination of personality to impersonality in his conception of the corporate form. As Cameron continues,

For Hobbes, the definition of a person (or agent) is what we agree to treat as a person; a being is determined human not by philosophical definitions or by man, but by law. To be a person or agent, according to Hobbes, it is not sufficient to consider yourself a person; you must also be considered as possessing agency. In distinction, personality stresses self-ownership, the of or possessive through which individuality is identified as one's own. Impersonality is an idea that Eliot made commonplace. But whereas Eliot coined the word narrowly to indicate the extinction of personality that defines the artist, this extinction ... has different contours ....

64 Sharon Cameron, Impersonality: Seven Essays viii (2007). 
for example, in attributing a new kind of exceptional, and exceptionally protected, agency to the impersonal. ${ }^{65}$ Cameron develops a persuasive cultural reading of impersonality, but her focus does not extend to the corporation. Since the state is a precursor to and, in effect, author of the corporation, one should also consider the agency and personification of the modern nation-state as the historical backdrop for the staging of corporate personhood.

Hobbes is one of the first modern theorists of agency and agency law-his work addresses who can represent whom and what, on whose behalf, and with what responsibility and liability. As Quentin Skinner observes, Hobbes "informs us in Chapter XVI of Leviathan [titled "Of Persons, Authors and Things Personated"] that the state can actually be defined as "One Person." ${ }^{66}$ Considering how impersonal beings or associations can act or have intent, Skinner notes that Hobbes somewhat disingenuously proposes that it is possible

for an action genuinely to be attributed to a collectivity-or to an abstraction or even a thing - provided that one particular condition is met. The agent to whom the action is attributed must be represented by another agent who can validly claim to be 'personating' the first by way of acting on their behalf. ${ }^{67}$

Similar considerations apply to the corporation in terms of impersonality, ventriloquism, a kind of bootstrapped inhuman identity, and the attribution of liability. Hobbes elucidates the modern division between actual and artificial persons and what later emerges as an attendant split between agency and responsibility. Though he cites historical and cultural precedents for this split, Hobbes ultimately is making a contemporary legal justification for the distinction; the critical difference is not between human person and artificial collective, but human person acting on his or her own behalf and human person acting on behalf of someone or something else:

PERSON, is he, whose words or actions are considered, either as his own, or as representing the words or actions of another man, or of any other thing to whom they are attributed, whether Truly or by Fiction. When they are considered as his own, then is he called a Natural Person and when they are considered as representing the words and actions of another, then is he a Feigned or Artificial person. ${ }^{68}$

In the language of artifice, fiction, acting, and impersonating, agency would have no logical constraints, as it is conceived as transitive; in Leviathan, to act is equally to do and to fake and impersonate. Hobbes here conceptualizes what we might call the modern imperson-nation, and the legal framework that sanctions and relies on corporations.

$I d$. at viii (eio).

66 Quentin Skinner, Hobbes and the Purely Artificial Person of the State, 7 J. PoL. PHIL. 1, 3 (1999).

67 Id. at 3-4.

68 Thomas Hobbes, Leviathan: Or, The Matter, Forme \& Power of a Commonwealth, ECClesiasticall AND Civil 110 (A.R. Waller ed., 1904) (1651) (language modernized). 
Addressing how Hobbes classifies fictions of personhood (which become salient for the creation of corporations), Skinner observes that

Hobbes proposes no particular term to isolate this category, but it may be helpful to designate them purely artificial persons to distinguish them from those who voluntarily take on this status by authorizing others to represent them. . . . Hobbes [indicates] that two sub-classes need to be considered: those whose words and actions can be 'truly' attributed to them, and those who can only have words and actions attributed to them 'by Fiction.' Nothing further is said in Leviathan about the class of purely artificial persons who are also fictitious. But in De Homine it emerges that what Hobbes has in mind are the characters impersonated by actors on the stage: For it was understood in the ancient theatre that not the player himself but someone else was speaking, for example ....

If I play the part of Agamemnon on the stage, the actions I perform . . . will not 'truly' be taken to be Agamemnon's actions, however, but only 'by fiction' and a willing suspension of disbelief. This will especially be the case if I follow the convention of pointing out that I am merely engaged in a performance. ${ }^{69}$

This formulation of acting and impersonation will later inform many aspects of the corporate enterprise, from the ascription of agency (but usually not liability) to corporate representatives to the reliance on actors who act as surrogate corporate persons in advertising.

Skinner identifies the initial bases for artificial agency or personhood, which also provide a foundation for the development of artificial rights:

Hobbes regards some human beings as purely artificial in this sense. But he is more interested in the fact that various inanimate objects and even figments of the imagination can be classified in a similar way. ... Since these are 'things Inanimate' they 'cannot be Authors, nor therefore give Authority to their Actors.'

Nevertheless, they can perfectly well be personated or represented 'by a Rector, Master, or Overseer' who can be commissioned and thereby given authority to act on their behalf. Among imaginary objects he singles out the gods of the heathen. Such idols obviously cannot be authors, 'for an Idol is nothing." Nevertheless, in ancient times such deities were frequently recognized as having the ability not merely to own possessions but to exercise rights. As in the case of the hospital and the bridge, these capacities stemmed from the fact that authorized persons (in this case officiating priests) were assigned a legal right to act in their name. ${ }^{70}$

The corporation emerges as a successor to these deities, Nature, and finally the sovereign that created the corporation. (Over a protracted period, the Supreme Court

Skinner, supra note 66, at 15 .

Id. at 16. 
has extended Hobbes' exegesis by declaring that corporations have become authors that not only have the right to express speech, but possess authentic, identifiably human voice and agency).

Hobbes, however, believed the representative/sovereign and those who authorized him were accountable for their actions, and that those actions could be directly ascribed to their agents; he authorized the exercise of power, not its absolution. But the power concentrated in the body of the sovereign has become concentrated in the body of the corporation - an artificial body even more removed from people. Wanting the state to restrain and regulate individual violence and economic crime, Hobbes believed an impersonal system could regulate the behavior of personal players. But the impersonal corporation increasingly took over, and it is in critical ways unregulated and unchecked in power; this denouement reflects a systemic corruption of the principles that hypothetically justified the legitimate but limited function of corporations. In this Hobbesian lineage, the sovereign state charters/creates/empowers the Mephistophelean corporation that will inevitably try to commit state parricide.

In Leviathan, Hobbes repeatedly prioritizes the shared, the proto-universal, and the common. The notion of the commonwealth is predicated on a sharing of things that cannot be divided: for example, the common interest; the common law; and what Hobbes frequently terms common discourse. According to Norberto Bobbio, Hobbes defines corporations as subordinate associations, which have as their ends "certain common activities for some common benefit or of the whole city." ${ }^{71}$ Hobbes evidenced what J. G. A. Pocock situates as a humanist dedication "to the common weal," but that commitment was coterminous with his notion that the state was not a "common" republic per se, but a corpus with a prince as the head..$^{72}$ In structural terms, the contemporary corporation is programmatically able to consider and factor largely if not exclusively only the good of itself, not the common - it is a body that is at war with parts of itself. Common wealth in fact becomes a term that is incommensurate with the corporate charter; axiomatically, what is good for X corporation is not good for America, because corporate profit is designed to be extracted for select private interests at the expense of the public good. If, in Catholicism, personal wealth was an obstacle to the progress of the soul and a sign of preterition, the impersonal wealth of the corporation becomes, in sociological contexts, sacralized, and a sign not only of the corporation's status as saved, but as having a soul to be saved.

In Hobbes' writing, we can see that the creation of the modern state was in many ways coterminous with the creation of the proto-corporate enterprise. In Leviathan, Hobbes already envisioned corporations as parasites on the state and as corrupt bodies even as he valorized their advantages: he effectively warns us of "the great number of corporations which are, as it were, many lesser commonwealths in the bowels of the greater, like worms in the entrails of a natural man." ${ }^{173}$ Hobbes still can imagine an assembly at which corporators gather to make and implement decisions:

\footnotetext{
71 Norberto Bobbio, Thomas Hobbes and the Natural Law Tradition 179 (1993).

72 J. G. A. Pocock, The Machiavellian Moment: Florentine Political Thought and the AtLantic Republican Tradition 339 (1975).

73 HobBes, supra note 68, at 241 (language modernized).
} 
In a body politic, for the well ordering of foreign traffic, the most commodious representative is an assembly of all the members; that is to say, such a one as every one that adventures his money may be present at all the deliberations and resolutions of the body, if they will themselves. For proof whereof we are to consider the end for which men that are merchants, and may buy and sell, export and import their merchandise, according to their own discretions, do nevertheless bind themselves up in one corporation. It is true, there be few merchants that with the merchandise they buy at home can freight a ship to export it; or with that they buy abroad, to bring it home; and have therefore need to join together in one society, where every man may either participate of the gain, according to the proportion of his adventure, or take his own, and sell what he transports, or imports, at such prices as he thinks fit. But this is no body politic, there being no common representative to oblige them to any other law than that which is common to all other subjects. ${ }^{74}$

Most contemporary shareholder meetings are removed from such a scenario not only because of our economies of scale, but because modern corporations are designed to separate shareholding owners from managers. One could say that instead of checks and balances, the corporate structure is designed to provide free passes.

The "body politic" - and the notion that society is an organic community, a social body - is supplemented and deformed by the corporation, another fictitious aggregate body, representing an entity that is precisely immaterial. If, in traditional, conservative social theory, "the presupposed organic unity of Society is perturbed by the intrusion of a foreign body," the unity of our society is now in many ways predicated on the presence of a foreign body - the corporation. ${ }^{75}$ But in this schema, the very conceit that society is or should be an organic unity is, aside from posing inherent problems in a multicultural and hierarchical society, easily co-opted. One might say that the always phantasmic corporate body ventriloquizes a voice without a source. In the modern corporation, the Hobbesian social body is bifurcated to bypass common interest, which effectively means the public good itself becomes a foreign/alien element to the corporate body. (This bifiurcation is in some ways homologous with what Anna Grear documents at length, in the context of the legal creation of personality, as the "problematic gap that legal disembodiment creates between the living human being and the legal entity or construct taken to represent the human being." ${ }^{\prime \prime 6}$ The separation between artificial corporation and organic human being has, by the end of the nineteenth century, become absolute. By the time of Button v. Hoffman, U.S. courts had decided that even a corporation owned by a single person exists independently of that owner; Walter Benn Michaels contends that consequently the corporation no longer represents a veil concealing a man or woman, but is itself a new kind of person. ${ }^{77}$

\footnotetext{
Id. at 164 (language modernized).

ŽIŽEK, supra note 29, at 127.

Anna Grear, Redirecting Human Rights: Facing the Challenge of Corporate Legal Humanity 149 (2010).

77 Button v. Hoffman, 20 N.W. 667 (Wis. S. Ct. 1884); Michaels, supra note 34, at 197.
} 


\section{MASS INCORPORATION}

As the idea has played out in U.S. culture, to incorporate is not to join a common society, but to transcend individuality - in a society putatively obsessed with individuality - in some larger natural or artificial body. To incorporate is in some ways to merge one's individual body into a collective body, to renounce human limitations, and, in the centuries after Hobbes, the common in favor of the private shareholder. But the paradox is that many corporations systematically invert the characteristics of the public and the private, from concepts of privacy to those of public benefit and welfare. In Democracy in America, Tocqueville concluded that pantheism, the aforementioned deification of an impersonal Nature, represented a seductive form of specifically American incorporation:

If there is a philosophical system which teaches that all things material and immaterial . . . are to be considered only as the several parts of an immense Being, who alone remains eternal amidst the continual change and ceaseless transformation of all that constitutes him ... such a system, though it destroy the individuality of man, or rather because it destroys that individuality, will have secret charms for men living in democracies. ... It naturally attracts and fixes their imagination. ${ }^{78}$

In other words, Tocqueville situated Nature as the American leviathan. The transcendent system he evoked at first took the shape of Nature, to a lesser degree the nation-state, and finally, after the Civil War, the immense Being of the corporation..$^{79}$ Again, the corporate body is itself an amalgam, a conglomeration of bodies turned into something monstrous in scale and form, which is why it can be evoked via leviathans and artificial bodies of many kinds. The "body" or community we belong to is that of the corporation, which is no longer organized around or participates in any exchange involving the munus or gift, but transactions that are part of a zero sum game. While writers such as Hobbes, Tocqueville, and Emerson invoke a language that seeks "common" nature that will create a common wealth, the mass, immortal corporate version of that common body winds up impersonally seducing, absorbing and dissolving its members. In Lectures on the Pantheistic Idea of an Impersonal Deity (1864), Reverend Morgan Dix proposed we imagine "this indescribable, this immense condition, or mass, or state (or by whatever name you wish to call it) and you have before you the only eternal being. Let us apply to it, for the sake of convenience, the term God." ${ }^{80}$ (One of Emerson's terms for the immense being of divine Nature was "the Over-Soul." It is particularly ironic that the corporation, which is immaterial, attains the figurative body with the most mass in the world). That immense, eternal corporate body was imagined to possess

78 Alexis de Tocqueville, Democracy in America II 31-32 (Phillips Bradley, ed., Henry Reeve trans., Francis Bowen, rev., 1953).

79 Constraints of space prevent me from addressing a concept that is, in any case, likely familiar to most readers, but, as many critics have documented — particularly with regard to the way the fascist state promulgated fantasies of an "organic" body of society- the nation-state often has been devised in conjunction with images of a unified, mass body.

80 Rev. Morgan Dix, Lectures on the Pantheistic Idea of an Impersonal Deity 22 (1864). 
a soul, but as it became increasingly impersonal, it also became clear it functioned without a mind.

After the Civil War, virtually all transcendental rhetoric of Union in Nature became deflected to rhetorics of incorporation (which in figurative terms also often entailed individual dismemberment). The sometimes seemingly abstract contest between the individual and the corporate mass is evident in more concrete terms, for example, in the jury instructions of an 1886 Mississippi Supreme Court case:

This poor negro has the same right to have his matters adjudicated as the defendant, but things have come to such a pass in this country that a railroad company is very much injured if an humble man dares to bring them into the courts. If he dares to appeal to the juries of the country, it is high treason. I say you must consider who the parties are, and who is more likely to overawe witnesses, -a corporation of this sort, or a private individual. I put it to your own knowledge of human nature, whether it is not true that immense corporations, controlling immense armies of operatives, are not more likely to overawe witnesses ... ${ }^{81}$

Again, it seems illustrative that the personhood of an African American is here being pitted against the immense personhood of the corporation in terms of legal speech. Subsequent cases often have referred to the unprecedented power of "immense corporations," ${ }^{82}$ and to corporations as immense agglomerations: see, e.g., Nw. Union Packet Co. v. Shaw (acknowledging that "that the transportation of the products of the country is mainly controlled by powerful corporations, representing immense aggregations of capital"); ${ }^{83}$ McCarter v. Firemen's Ins. Co. (addressing "the enormous extension of this business, by its concentration in the hands of immense corporations, by state regulations that amount to privileges") $;^{84}$ Com. v. Copperman (stating that we live in the "days of giant corporations, great railroad companies, immense industrial and financial organizations"); ${ }^{85}$ and Race Safe Sys., Inc. v. Indy Racing League (referring to "an immense multi-national corporation"). ${ }^{86}$ As the Court noted - apparently without irony or alarm-most recently and disturbingly in Citizens United v. Federal Election Commission, "media corporations accumulate wealth with the help of the corporate form, [and] the largest media corporations have "immense aggregations of wealth." "87

Accumulation and aggregation are usually zero-sum games; the more money, power, sheer mass and ontological privilege corporations have, the less is left to individuals. As many science fiction films suggest, we increasingly feel as if we are being fed into a giant machine. Transcendentalists had fantasized that Nature was a bulwark against and alternative to the mechanistic corporation and the emerging corporate society, but the language used to evoke both entities revealed a discursive and ontological commonality. Emerson had wanted men to merge into Nature and

\footnotetext{
Newman v. Vicksburg \& M. R. Co., 64 Miss. 115, 122 (Miss. 1886).

St Louis Gaslight Co. v. City of St Louis, 84 Mo. 202, 204 (Mo. 1884).

Nw. Union Packet Co. v. Shaw, 37 Wis. 655, 660 (Wis. 1875).

McCarter v. Firemen's Ins. Co., 74 N.J. Eq. 372, 381 (Ct. Err. \& App. 1909).

Com. v. Copperman, 26 Pa. D. 763,769 (Pa. Com. Pl. 1917).

Race Safe Sys., Inc v. Indy Racing League, 251 F. Supp. 2d 1106, 1108 (N.D.N.Y. 2003).

Citizens United v. Fed. Election Comm'n, 558 U.S. 310, 348 (2010).
} 
not society. In his overtly Hobbesian mode, Emerson notably warned in "SelfReliance" that "Society is a joint-stock company, in which the members agree, for the better securing of his bread to each shareholder, to surrender the liberty and culture of the eater. The virtue in most request [sic] is conformity. Self-reliance is its aversion. $"{ }^{88}$ But by self-reliance, Emerson always meant god-reliance-reliance on an archetypal self that transcended individuality and became representative. Emerson believed only in an "aboriginal self," a self displaced by the archetypal and the Over-Soul. ${ }^{89}$ Ironically, in trying to avoid merging with the corporate society/ state, Emerson proposed merging with a Nature even more corporate, immense, impersonal and dispossessing. ${ }^{90}$

In Moby-Dick, Ishmael tries to imagine an alternative to the social-commercial enterprise of his nation, even as he embarks on a commercial whaling expedition, by "merg[ing his] own individuality" with Queequeg "in a joint stock company of two." (Ishmael's opinion of actual corporate enterprises is evident in his observation that much as men in the ideal might be commendable, they "might seem detestable as joint stock-companies and nations"). ${ }^{92}$ In letters to Hawthorne, Melville expressed the same longing to merge male bodies to create a composite body, even while always acknowledging that such desires for transcendence were either absurd or potentially self-destructive: "spread and expand yourself, and bring yourself to the tinglings of life that are felt in the flowers and the woods, that are felt in the planets.... What nonsense! ... This 'all' feeling, though, there is some truth in it." ${ }^{\prime 93}$ What Romain Rolland later terms the oceanic feeling turns out to represent a longing to be immersed in a corporate form; we don't transcend painful, isolated individuality by trying to merge with Nature, but the corporation. As in Mardi, the pantheist spreads or merges into the immense body of Nature or the planet itself. Often used to evoke experiences of reverie with Nature, the discourse of merger generates a language of both social connection and utter disindividuation. As he grows more cynical than even Ishmael, the young pantheist Pierre, in Melville's next novel after Moby-Dick, represents the transition from transcendental to corporate pantheism. At first, the text assures us, "you lose your sharp individuality, and become delightfully merged in that soft social Pantheism, as it were, that rosy melting of all into one ... no one draws the sword of his own individuality." 94

\footnotetext{
EMERSON, supra note 23, at 49-50.

Id. at 63 .

90 See generally my "Not Altogether Human": Pantheism and the Dark Nature of THE American Renaissance (2012).

91 Melville, supra note 9, at 320.

$92 \quad I d$. at 117.

93 Herman Melville, Correspondence 193-94 (Lynn Horth ed., 1993).

94 Melville, Pierre; OR, The Ambiguities 250 (Harrison Hayford, Hershel Parker,
} G. Thomas Tanselle eds., 1968). Nathaniel Hawthorne also documents Americans' desire to transcend their atomized individualities in the same transcendental/corporate language: in The House of the Seven Gables, his narrator reflects on the ways a human procession "melts all the petty personalities of which it is made up, into one broad mass of existence — one great life - one collected body of mankind, with a vast, homogeneous spirit animating it." Nathaniel Hawthorne, The Centenary Edition of the Works of Nathaniel Hawthorne 2, 165 (William Charvat, et al., eds. 1965). Such descriptions are commensurate with those of Emerson or Tocqueville, save that that the antipantheistic Hawthorne typically imagines merger only in society. Hawthorne's narrator 
Not coincidentally, when Pierre renounces his pantheism, he rages at an imagined Goethe: "Already the universe gets on without thee, and could still spare a million more of the same identical kidney. Corporations have no souls, and thy Pantheism, what was that? Thou wert but the pretentious, heartless part of a man. Lo! I hold thee in this hand, and thou art crushed in it like an egg from which the meat hath been sucked." ${ }^{95}$ This passage succinctly dismantles the apparent opposition between Nature (pantheism) and corporation. Stripped of its soul, the corporate body is dismembered instead of unified; the many forms of American pantheism that would merge us into the body of universal Nature turn out to vivisect shareholders into organs and body parts.

I don't have space to document the assertion at length, but American pantheists emblematically seek to transcend the boundaries of individual male identity, and merge with other men into collective Nature; and they lose individual agency and will, believing that their actions become archetypal and even involuntary in Nature. These processes actually comport with the premises of, and culminate in, the post-industrial corporation. The language of pantheism is one of merger into Nature - a rosy melting of all into one, or the one into the divine All. ${ }^{96}$ That rhetoric of merger in Nature has become that of corporate merger and incorporation. Ironically, though it remains the symbol of capitalism, the corporation from Hobbes onward is fiercely anti-individualistic in its organization, operation, premises and effects. If Hobbes conceived of the sovereign as a "God on earth," its initial extension and final successor, the corporation, this indescribable mass, comes to attain not only its own soul, but the power to create and steal souls, making it a kind corporate Over-Soul. ${ }^{97}$

Instead of merging with Nature, a prospect writers such as Emerson and Whitman extolled, people began merging into corporations: Michaels asserts, for example, that for Cyclone Davis, "the individual is merged in the money machine of which he is an integral part." 98 The corporation represents a mechanical version of a transcendental Nature that is revealed to have been mechanical all along. It is

claims that "a family should be merged into the great, obscure mass of humanity": not into nature or the ocean itself, but into the "great current of human life." Id. at185, 256. But that great mass or immense Being often becomes a corporate entity, as partly again signaled by the role of the railroad in Hawthorne's novel.

95 Melville, supra note 94, at 302. Pierre's claim that corporations have no souls might be derived from James Fenimore Cooper's The Bravo, which vilifies the "soulless corporation[s]" of secret deliberative bodies, as well as a legal lineage traced back to England's Chief Justice Coke in the seventeenth century. James Fenimore CoOper, The Bravo: A TALe 170 (1859).

96 I address this dynamic of merging in full in "Not Altogether Human," but D. H. Lawrence offers a useful summary, for example, of Whitman's pantheism: "Merging! And Death! Which is the final merge." D. H. Lawrence, Studies in Classic American LitERATURE 178 (1964). Emerson and many pantheists fetishize this imagined merger as ego-transcendence; in Moby-Dick, Ishmael both is and warns us of the man who "takes the mystic ocean at his feet for the visible image of that deep, blue, bottomless soul, pervading mankind and nature ... In this enchanted mood, thy spirit ebbs away to whence it came: becomes diffused through time and space: like Wickliff's pantheistic ashes .... Heed it well, ye Pantheists!" MD, supra note 9, at 159. That self is lost to the immense, overwhelming collective of Nature, which soon reemerges as the corporation. Michael Hardt \& ANTONio Negri, EmPire 85 (2000).

98 Michaels, supra note 34, at 200. 
not merely a rhetorical echo that the process of commercial aggregation is called a corporate merger, another manifestation of the ways corporations imitate and usurp psychological and ontological characteristics of people. The sociologists John Meyer and R. L. Jepperson contend that in earlier
religious polities, and in the secularized formations that eventually built upon them, spiritual charisma could be distributed across three main locations: (a) in a central institutional complex (a monarchy, a high Church, a state); (b) in the community as an organic body (that is, in a sacralized matrix of relations [e.g., a system of corporate orders] ); or (c) in spiritualized subunits (namely, individuals empowered as souls carrying responsibility for responsible action, whether individually or associationally). ${ }^{99}$

Here, I invoke the corporate idiom more literally: in the United States, opposed for example to much of Europe and Scandinavia, the role of organic community and the public sphere is to some degree displaced or supplanted by the artificial corporation. But the corporation remains closer to what Nature once represented than to the modern nation-state, as it exists outside conventional limitations and, in some ways, even individual oversight or management. In Meyer and Jepperson's schema, it is the corporation that has become citizen four.

As Melville established in Moby-Dick, after Hobbes, a corporation functions as a collective being without a body, an abstraction incorporated as a fictional leviathan: for Powers, it is "an aggregate giant, one that summed the capital and labor of untold Lilliputians into vast, limbered Leviathan." 100 As Frederic Jameson notes, "The market is thus Leviathan in sheep's clothing"; or as Joel Bakan puts it, by the turn of the twentieth-century, "Corporations were now widely viewed as soulless leviathans." ${ }^{101}$ In September 2014, The New York Times reported that "a European publishing executive likened [Google] to a Wagnerian dragon." 102 Powers encapsulates the corporate octopus or leviathan as an all-encompassing monomaniacal distillation of new world co-option: "The limited-liability corporation: the last noble experiment, loosing an unknowable outcome upon its beneficiaries. Its success outstripped all rational prediction until, gross for gross, it became mankind's sole remaining endeavor." 103 It is the gross and ubiquitous leviathan that threatens not only to supplant all other forms of commerce, but all other forms of ratiocination and identity. (One of the most disingenuous and misguided pronouncements in the Citizens United holding is Justice Kennedy's assertion that "Corporations, like individuals, do not have monolithic views." 104 As

\footnotetext{
99 John W. Myers \& Ronald L. Jepperson, The "Actors" of Modern Society: The Cultural Construction of Social Agency, 18 Soc. THeory 109 (2000).

100 Powers, supra note 7, at 158.

101 Fredric Jameson, Postmodernism, Or, the Cultural Logic of Late Capitalism 273 (1991); Joel Bakan, The Corporation: The Pathological Pursuit of Profit and POWER 17 (2005).

102 Danny Hakim, Google is Target of European Backlash on U.S. Tech Dominance, N.Y. Times, Sept. 9, 2014, at A1.

103 Powers, supra note 7, at 159 .

104 Citizens United, 558 U.S. at 364.
} 
I argue here and elsewhere, these are the only kind of views a corporation legally, and in most cases ontologically, can have. And as David Foster Wallace suggests in The Pale King, they precisely give rise to what is called "in economic terms [a] 'monoculture." "105 As George Steiner observes, in translatable contexts, "The thought of a more or less monoglot world is no longer inconceivable." ${ }^{106}$ According to David Harvey, we should see post-war Fordism "less as a mere system of mass production and more as a total way of life," and one might modify that term as totalizing. ${ }^{107}$ At the level that affects the vast majority of Americans on a daily basis, the culture of corporations is a monomaniacally monotonous infestation-it requires not just mass production and consumption, but mass culture, a kind of monopolistic consolidation of wealth, power, networks of distribution, and speech under the façade of diversity. It is not accidental, but a necessary consequence of corporate unification, universality and Hobbesian sovereignty that we increasingly are exposed, at any meaningful level and in almost the entire developed world, primarily to corporate media and art: the monopoly corporations most tend to effectuate is not primarily economic, but psychological, cultural, sociological, and ontological.

\section{BEHIND THE VEIL}

Hobbes imagined the very purpose of the corporation was to corner markets - and in some sense to consolidate those who give it agency into its aggregate being:

The end of their incorporating is to make their gain the greater; which is done two ways: by sole buying, and sole selling, both at home and abroad. So that to grant to a company of merchants to be a corporation, or body politic, is to grant them a double monopoly, whereof one is to be sole buyers; another to be sole sellers. For when there is a company incorporate for any particular foreign country, they only export the commodities vendible in that country; which is sole buying at home, and sole selling abroad. For at home there is but one buyer, and abroad but one that selleth; both which is gainful to the merchant, because thereby they buy at home at lower, and sell abroad at higher, rates: and abroad there is but one buyer of foreign merchandise, and but one that sells them at home, both which again are gainful to the adventurers. ${ }^{108}$

Hobbes realized that unless restrained, the corporate structure would tend to generate monopoly, colonialism, and a concentration of wealth and power, but he was concerned with codifying the benefits of the novel form, not anticipating their pernicious mutations. Through the corporate entity and the conceptual corporation, we've created a system that encourages and necessitates the concentration of wealth and the circumnavigation of liability. Though the power

05 WALlaCE, supra note 40, at 271.

106 George Steiner, Errata: An Examined Life 113 (1997).

107 HARVEY, supra note 10, at 135.

108 HobBes, supra note 66, at 164. 
behind a corporation is usually diffuse in the sense of being unlocatable, Barry Lynn documents the rise of a powerful class that "communalized all its holdings" in corporations and "thus escaped the legal strictures that tie individual owners to real property. Even when that power is momentarily concentrated in the body of a real person ... the interest remains only to maximize capital and hence power." 109

What kind of person or personhood exists beneath the corporate veil, the legal shroud that obscures the non-existent Oz? For Hobbes, personhood itself is a mask or performance, and we all present ourselves to the world through personae that constitute personhood:

The word person is Latin, instead whereof the Greeks have prosopon, which signifies the face, as persona in Latin signifies the disguise, or outward appearance of a man, counterfeited on the stage; and sometimes more particularly that part of it which disguises the face, as a mask or vizard: and from the stage hath been translated to any representer of speech and action, as well in tribunals as theatres. So that a person is the same that an actor is, both on the stage and in common conversation; and to personate is to act or represent himself or another; and he that acts another is said to bear his person, or act in his name . . . and is called in diverse occasions, diversely; as a representer, or representative, a lieutenant, a vicar, an attorney, a deputy, a procurator, an actor, and the like. ${ }^{110}$

Under Hobbes' framework, the primary character or dramatis persona in U.S. culture has become the corporate mask/person. It is necessary to digress here briefly to connect Hobbes' evocation of the representative actor to Emerson's conception of the representative man, because both types directly belong to the lineage of impersonal corporate personhood in the U.S. Emerson remains important here because his apparent idealization of American individualism turns out to be a representative proselytization for corporate identity.

Advocating that we pursue a purely representative, aggregated existence (which would ultimately entail an ascension to impersonal genius), Emerson is interested only in the "moments in the history of heaven when the human race was not counted as individuals, but was only the Influenced, was God in distribution." 111 God or the corporation gathers these distributed individuals or fragments into a collective mass existence that transcends locality and particularity. Contrary to popular misconceptions of his notion of self-reliance, Emerson rarely considers anyone or anything in individual terms: as he admonishes with unusual precision, "We fancy men are individuals; so are pumpkins." 112 Throughout his essays and journals, Emerson averred that God is "no respecter of persons," and that in our truest relations with the divine and ourselves "there is no personeity in it." 113 For

109 Barry C. Lynn, Cornered: The New Monopoly Capitalism and the Economics of Destruction 242 (2009).

110 HobBEs, supra note 66, at 110 (language modernized).

111 I Ralph Waldo Emerson, The Method of Nature, Works, supra note 23, at 210.

112 III Ralph Waldo EMERSon, Nominalist and Realist, Works, supra note 23, at 246.

113 Ralph Waldo Emerson, The Journals and Miscellaneous Notebooks of Ralph 
Emerson, the representative man must "disindividualize himself" and align with "the universal mind." 114 "In "Fate," Emerson promises and warns that the Law of Nature "dissolves persons." 115 Again, the corporation now implements this law. Though his Laws of Nature promise a compensatory unity, Emerson periodically concedes the cost: "These forces are in an ascending series, but seem to leave no room for the individual." 116 In Emerson's highly corporate Nature, the uniformity and universality of natural law is paramount, and truth is effectively equivalent to mass; for Emerson, "the individual is always wrong." 117

Emerson believed Nature spoke through him in ways that turned him into a kind of corporate spokesperson for larger forces: "Through me, God acts; through me, speaks." 118 Such sentiments recur throughout Emerson, though they are voiced most directly in his writings of experience. Emerson finally fears that "nothing is of us or our works - that all is of god. Nature will not spare us the smallest leaf of laurel. All writing comes by the grace of God." 119 A version of Tocqueville's immense divine being, the corporation again seems to displace the function of Nature; it bears the transcendental, collective identity that speaks through us. But even more ominously, the apparent opposition between Nature and corporation disappears, a process symbolically concluded as corporations begin to control most forms of media speech, patent genes and seeds, and effectively modify and create life. ${ }^{120}$

In Hobbes' proto-corporate conception, to be a person is already a corporate personification. Hobbes then distinguishes between personally-validated acts and authorized acts, which are essentially impersonal or impersonations:

Of persons artificial, some have their words and actions owned by those whom they represent. And then the person is the actor, and he that owns his words and actions is the author, in which case the actor acts by authority. For that which in speaking of goods and possessions is called

WaLdo EMerson V 170 (William Gilman, et al. ed., 1965).

114 VII Ralph Waldo Emerson, Art, Works, supra note 23, at 48-49.

115 VI Ralph Waldo Emerson, Fate, Works, supra note 23, at 49.

116 X Ralph Waldo Emerson, Perpetual Forces, Works, supra note 23, at 72.

117 III Ralph Waldo EMERSOn, Experience, Works, supra note 23, at 69.

118 III Ralph Waldo Emerson, Divinity, Works, supra note 23, at 129.

119 EMERSON, supra note 117.

120 Emerson's theory of self-reliance was misappropriated not via social Darwninism, as Howard Horwitz suggests, but by common misinterpretations that rely on generic and highly inapposite definitions of the self. For Emerson, self-reliance entails the evacuation of the individual self into an archetypal All or whole,--into a purely representative, typological, and finally corporate entity that eradicates false particularity. The transcendental corporate structure of agency Horwitz invokes is indeed Emersonian, but not because Emerson extolled individualistic exploits as they are commonly understood, but because for Emerson the transcendental individual is stripped of all individuality. The transcendentalist precisely transcends the self by merging into the divine aggregate, whether in Nature or the corporation. Howard Horwitz, The Standard Oil Trust as Emersonian Hero, Raritan 6.497 (1987). Emerson is then corporate in ways I would argue are disparate from those that Christopher Newfield identifies in other contexts. See generally Christopher Newfield, The EMerson EfFect: Individualism AND SubMission In AMERICA (1996). 
an owner ... speaking of actions, is called author. And ... by authority is always understood a right of doing any act; and done by authority, done by commission or license from him whose right it is.

From hence it follows that when the actor makes a covenant by authority, he binds thereby the author no less than if he had made it himself; and no less subjects him to all the consequences of the same. ... ${ }^{121}$

The imperatives of impersonal corporations allow individuals to do what they likely would not do in their own names - they become authorized, or are given license, to act in ways individuals on their own would resist or reject. (In this sense, the corporation operates as the largest diffused military corp. in the history of the world). In considering who and what can be "personated," Hobbes adumbrates the contemporary animation of fictions and things:

There are few things that are incapable of being represented by fiction. Inanimate things, as a church, a hospital, a bridge, may be personated by a rector, master, or overseer. But things inanimate cannot be authors, nor therefore give authority to their actors: yet the actors may have authority to procure their maintenance, given them by those that are owners or governors of those things. And therefore such things cannot be personated before there be some state of civil government. ${ }^{122}$

In the final teleology of the corporation, inanimate things will be able to become actors. ${ }^{123}$ Like forms of AI, corporations, with varying degrees of plausibility, both imitate and transcend human beings. The corporation seems to be invisible, disembodied and immortal - all signs of ineffable power - and therefore seems to attain transcendent or numinous properties, and represent an immanent force. As I argue, the corporation thereby displaces Nature, the nation-state and to some degree almost all prior institutional aggregates.

Hobbes' disquisitions are concerned with the forms of safety and security that depend on the guarantees of the state, but also set the boundaries of what constitutes a person with rights and identity:

Likewise children, fools, and madmen that have no use of reason may be personated by guardians, or curators, but can be no authors during that

21 HobBes, supra note 66, at 110-11 (language modernized).

${ }^{122}$ Id. at 112.

123 Our diurnal experience of the corporation inures us to systemic depersonalization. When a corporate on-hold message tells you "your call is very important to us," it mocks your personhood; making such statements is akin to telling every person you pass on the street indiscriminately and mechanically that you're in love with them. When I email Wells Fargo bank, I receive the following automated message: "Thank you for sending your service request to Wells Fargo. As one of our most valued customers, your questions and concerns are our highest priority." These sentences were at some point written by a person (though a functionally illiterate one, since my questions are not one of their most valued customers). But the absurdity of sending a generic, automated reply that claims to initiate a personal relationship - that values you personally, or recognizes you - communicates the essence of the artificial intelligence of corporate personhood. 
time of any action done by them, longer than (when they shall recover the use of reason) they shall judge the same reasonable. Yet during the folly he that hath right of governing them may give authority to the guardian. But this again has no place but in a state civil, because before such estate there is no dominion of persons. ${ }^{124}$

Here, Hobbes also considers the status of combinations of persons: what they represent; whom they can represent; and how they differ from individual actors:

A multitude of men are made one person when they are by one man, or one person, represented; so that it be done with the consent of every one of that multitude in particular. For it is the unity of the representer, not the unity of the represented, that makes the person one. And it is the representer that bears the person, and but one person: and unity cannot otherwise be understood in multitude.

And because the multitude naturally is not one, but many, they cannot be understood for one, but in any authors, of everything their representative say or do in their name; every man giving their common representer authority from himself in particular, and owning all the actions the representer does, in case they give him authority without stint: otherwise, when they limit him in what and how far he shall represent them, none of them owns more than they gave him commission to act. ${ }^{125}$

In elucidating the authority of the state, but also the authority collectives bestow upon agents, Hobbes advocates conditions of corporate organization that almost inevitably would be hijacked. People now surrender their rights and "ontologies" not just to governments, but corporations, which likely have a greater impact on our daily lives, environment, and identities than governments do. (Where citizens once putatively entered a priori "bargains" with the sovereign in exchange for order and safety, consumers now effectively enter innumerable a priori "bargains" with corporations surrendering not only their rights to sue, hold them liable, and so forth, but the possibility of living as free agents).

Today, the corporation acts as this Hobbesian unity-it is ubiquitous, inescapable and perhaps the greatest force of consolidation in history. According to Peter d'Errico, the role of the judiciary has been to turn the fiction of the corporate person from a legal abstraction into a "real" person that now exists independently of the state (and effectively exists sui generously), that could then negotiate with the state as an independent actor with all the rights of a person. ${ }^{126}$ Such developments, and the aforementioned separation of capital from management, are scenarios Hobbes could not quite anticipate, and help vitiate the assurance of corporate accountability.

124 HobBes, supra note 66, at 112. See also Richard Hardack, Bad Faith: Race, Religion, and the Reformation of Welfare Law, 4 Cardozo Pub. L. Pol'y \& Ethics J. 539-649 (2006), for a comparison of how the U.S. government often has treated individuals and corporations in the context of welfare, gifts, oversight and public and private rights.

125 Id. at 113 (language modernized).

126 Peter d'Errico, Corporate Personality and Human Commodification, 9 Rethinking MARXISM 100-01 (1996). 
To sum up, Hobbes indicates that agents can impersonate anything; that all things can be personified; and by implication, that not only persons, but gods can be impersonated: as Hobbes avers, "Men Women, a Bird, A Crocodile, a Calf, a Dog, a Snake, an Onion, a Leeke [brooke], Deified." 127 The final species to add to that list is the corporation, or the corporate person - a deity made in man's worst image.

\title{
CONCLUSION
}

\section{FiCTIONS OF AGENCY}

\begin{abstract}
"In not having a face, or even body, the [corporate] Project garnered for itself enormous and far-reaching capabilities, while at the same time reducing its accountability and vulnerability — to almost zero. . . . There was no building, no Project Headquarters . . . . The Project was supragovernmental, supra-national, supra-everything — and infra too; that's what made it so effective."
\end{abstract}

Tom McCarthy, Satin Island ${ }^{128}$

In the corporation, collective, impersonal biography overtakes the individual life narrative. Writers such as Powers and McCarthy narrativize what Robbie Floyd-Davis documents as the corporate cooption of narrative and biographical discourses, evident, for example, in the ways corporations hire academicsespecially anthropologists, sociologists, and story-tellers - to help them directly and indirectly to tell stories about them. ${ }^{129}$ In terms of production-films, media and publishing - but also their "self"-representation, corporations are the dominant aesthetic and ontological influence in our culture. The rise of the corporation coincides with the cultural shift from individual (or self, agent, author, authority, etc.) to system. Powers observes that Tom LeClair's definition of the systems novel assumes that "the individual human cannot be adequately understood as an autonomous, self-expressing, self-reflecting entity, but must be seen as a node of an immensely complex network." ${ }^{130}$ We can see the corporation as one nexus for this network. Interested in transcendental connections that, in his own paraphrase of John Muir, hitch everything to everything else, Powers proposes a "new genealogy for th[at] systems novel," in which his hybrid form passes "realism' through 'metafiction' through relational processes" and "refract[s] the private through the public." 131 According to Thomas Frank, management theorists "announced that the corporation, as a creature called into existence by the market, was of a special and

127 HobBes, supra note 66, at 74 (language modernized).

128 Tom McCARThy, SATIN IsLAND 123-24 (2015) (eio).

129 Davis-Floyd, Storying Corporate Futures: The Shell Scenarios, in Corporate Futures: The Diffusion of the Culturally Sensitive Corporate Form 141 (George E. Marcus, ed., 1998).

130 Powers, supra note 39 , at 305-06.

131 Id. at 308-09. 
even a superhuman nature," and, most absurdly, a vital force of democratization..$^{132}$ Such corporations exigently pervert the ideals of unfettered capitalist individualism they putatively advance, since they are predicated on aggregation, uniformity, mass production, and impersonal discourses that impersonate human communication. The celebrity generated by corporate media is also a kind of second-generation impersonator, one who often also - beyond the way all people construct or perform identities - already has changed his or her name, face, history, and persona. As I argue in "New and Improved," above the corporation has to generate spokespersons to stand in for and voice its absent center, and by structural necessity those spokespersons have purely corporate identities.

Legally created as a screen for individuals - to shield them from liability - the corporation has come to serve as a screen for the systemic displacement of the individual. That is, the corporation is socially and ontologically devised to perform tasks that individuals cannot pragmatically and economically, but also legally and ethically, pursue. It is an impersonal and pre-programmed system designed to coordinate behavior that could harm the common good. No single person is generally responsible for, or even perpetrating, the acts of a corporation, and usually no one can be held responsible; individuality is in fact systematically purged and evacuated from the system.

As intimated, writers have been positing for centuries that corporations emblematically have no souls, yet are still attributed with wills. Jameson details how the corporate form can thwart historical-materialist notions of agency and teleology: Marxists had trouble conceiving of

Some nonindividual, meaningful, collective yet impersonal agency the mode of production] . . . still somehow a "subject," like the individual consciousness, yet now immortal, impersonal in another way, collective beyond the dreams of populism .... the trust, the monopoly, the "soulfull" corporation, with its new corporate law. ${ }^{133}$

To Jameson, this new form eviscerates the predicates of the laissez-faire individual; citing Walter Benn Michaels' work on Frank Norris' novel The Octopus, Jameson suggests that the corporation simultaneously becomes intangible and a machine, because it never conjoins a soul with a body. ${ }^{134}$ Like Nature before it, the corporation precisely accommodates contradictory traits because it has no intrinsic qualities: it is an amalgam of projections, fantasies, legal ascriptions, and appropriations. Quoting Michaels, Jameson assets that "The corporation comes to seem the embodiment of figurality that makes personhood possible, rather than appearing as a figurative extension of personhood." Suprapersonal agencies are unthinkable for the individual mind." 135 Again, the corporation, is supra, exceptional, transcendental. Jameson notes that for Michaels, the corporation is not the effect, fantasy or projection of the

132 Thomas Frank, Free Markets Killed Capitalism: Ayn Rand, Ronald Reagan, WalMart, Amazon and the 1 Percent's Sick Triumph Over Us All, SAlon (Jun. 29, 2014), http://www.salon.com/2014/06/29/free_markets_killed_capitalism_ayn_rand_ronald_ reagan_wal_mart_amazon_and_the_1_percents_sick_triumph_over_us_alli/, at 220-21.

133 JAMESON, supra note 101, at 215.

134 Id. at 216.

135 Id. 
individual, but the reverse; the individual is "a projection back from the collective," an illusion generated by and for the corporate enterprise. We do not create the Matrix, Skynet, or Monsanto - they create us. If the king originally had two bodies, one that represented a society as a whole, or the social body, the overdetermined corporate body has supplanted those bodies figuratively, nominally and politically.

In the 1920s, John Dewey noted that under "fiction theory," which construes corporate personality as a contrivance rather than actual, the corporation has no soul and therefore cannot be "guilty of delict," meaning liable, or perhaps culpable, for causing injury. ${ }^{136}$ In 2000, Thomas Frank alleged that "no one has seriously charged a corporation with "soullessness" for many years," but that pronouncement is oddly tone-deaf culturally, both retroactively and proactively. ${ }^{137}$ The king's "personality" once served as kind of carapace for the corporate body; now we are left with corporate personality, which is no human personality at all, a state of things that has ramifications across our entire culture. In The Pale King, whose title conjures the ruler of a kind of corporate wasteland, David Foster Wallace's characters invoke that same "damn soulless corporation," and one of them also presciently declaims, "I don't think of corporations as citizens. . . . Corporations aren't citizens . . . They don't have souls." 138 Wallace is consistent in invoking this language of depersonalization, having a character warn us that federalist politicians will be "underwritten by an inhuman soulless profit-machine" that will "convince Americans that rebellion against the soulless inhumanity of corporate life will consist in buying products from corporations that do the best job of representing corporate life as empty and soulless." 139

In the private sector that now barely can be distinguished from the public, Clay Timon, chairman of Landor Associates, the influential branding firm, insists that corporations, as brands, do have souls, and that those souls enable them to generate emotional connections with consumers. ${ }^{140}$ If society can suppose that a thing can be infused with life, it is inevitable that that thing will claim a soul. David Allen documents the historical processes through which corporations have attempted (what I would characterize as) the colonization of personhood: "Having secured legal standing as people under the Constitution by the mid 1800s, corporations began looking for other ways to establish their humanness. In the $1900 \mathrm{~s}$, corporations began focusing on social welfare issues and public relations to convince people they had a soul." ${ }^{141}$ The corporation is the quintessential inhuman thing allegedly imbued with a soul or human personality: a specter haunting the world that was never alive, whose agentless teleology is to convince us it is us.

136 John Dewby, The Historic Background of Corporate Legal Personality, 35 Yale L. J. 655, 668 (1925-1926).

137 FranK, supra note 132, at 226.

138 WALLACE, supra note 40, at 136-37.

139 Id. at 149. Wallace seemed to experience some of his own feelings of depression and inadequacy in terms similar to those he used to evoke the degradations of corporate culture: he described himself, for example, as feeling as if he were a fake person who suffered from "imposter syndrome.” D. T. Max, Every Love Story is a GHOST Story: A Life of David Foster Wallace (2012).

140 BAKAN, supra note 101, at 26.

141 David S. Allen, Democracy, Inc.: The Press and Law in the Corporate Rationalization of the Public Sphere 24-25 (2005). 